CRIDES Working Paper Series no. 4/2019

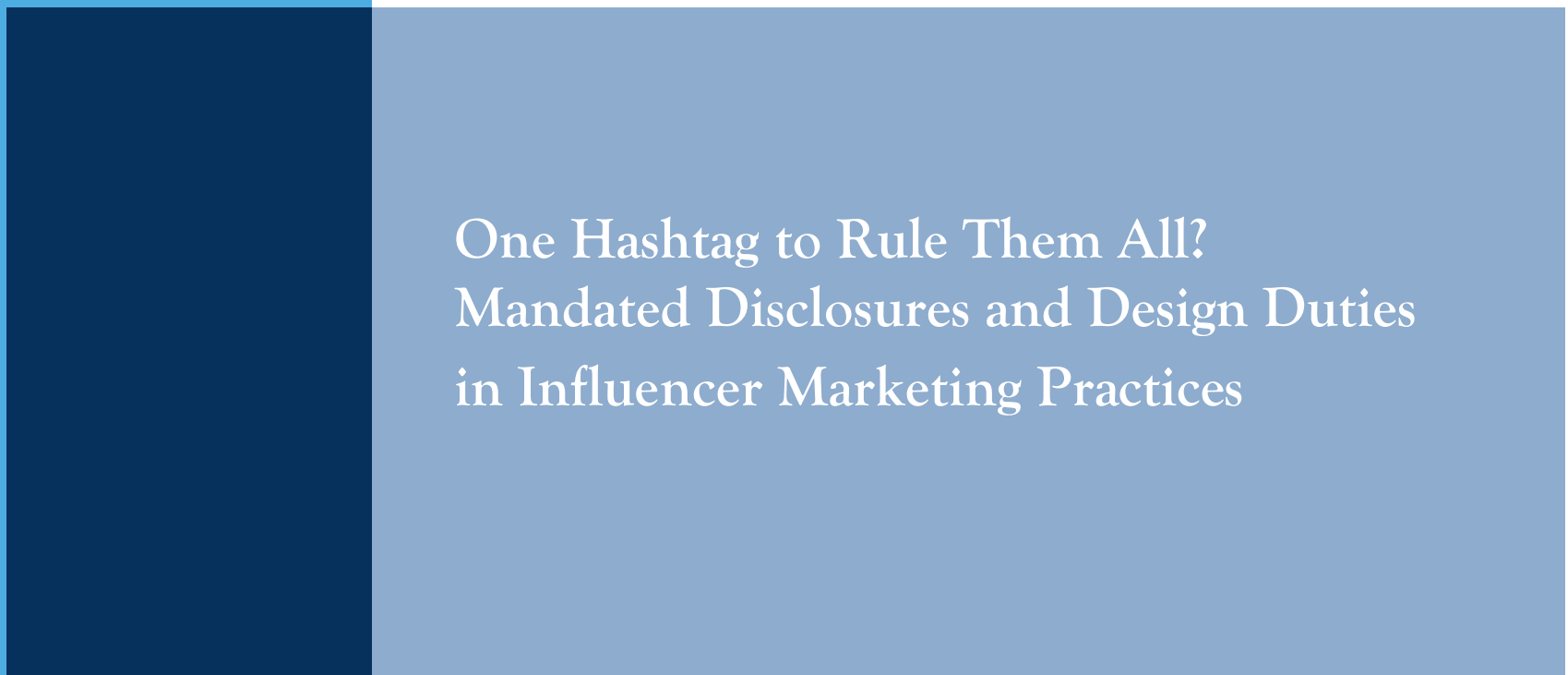

by Rossana Ducato

May 2019

Cite as: R. Ducato, One Hashtag to Rule Them All? Mandated Disclosures and Design Duties in Influencer Marketing Practices, CRIDES Working Paper Series no. 4/2019; to be published in Ranchordás, S. and Goanta, C. (Eds), The Regulation of Social Media Influencers, 2019, Edward Elgar Publishing, Forthcoming. 

The CRIDES, Centre de recherche interdisciplinaire Droit Entreprise et Société, aims at investigating, on the one hand, the role of law in the enterprise and, on the other hand, the function of the enterprise within society. The centre, based at the Faculty of Law - UCLouvain, is formed by four research groups: the research group in economic law, the research group in intellectual property law, the research group in social law (Atelier SociAL), and the research group in tax law.

www.uclouvain.be/fr/instituts-recherche/juri/crides

(c) (1) (-)

This paper (C) Rossana Ducato 2019 is licensed under a

Creative Commons Attribution-ShareAlike 4.0 International License

https://creativecommons.org/licenses/by-sa/4.0/ 



\title{
ONE Hashtag to Rule THEM All?
}

\section{MANDATED DISCLOSURES AND DESIGN DUTIES IN INFLUENCER MARKETING PRACTICES}

\author{
Rossana Ducato*
}

\begin{abstract}
Social media influencers (SMI) have become familiar figures over the last few years. We visit their profiles, watch their "stories", retweet, like and share their posts. Bloggers, vloggers, Instagrammers, Facebook Famous and Musers are terms that have entered our daily vocabularies and such people have established themselves as new celebrities.

However, the influencer phenomenon is not just about amusement. Considering the authority and reputation gained in the Internet arena, the value of SMIs - as a new generation of testimonials - has been promptly understood by brands and advertising professionals. A large part of marketing investment is now dedicated to securing the endorsement of influencers, and methods for identifying the relevant or emerging influencers in a given area have even been patented.

Influencer marketing is not prohibited a priori by law but has raised several concerns from a legal standpoint. When an SMI endorses a particular brand or product without clearly disclosing the marketing purpose of that communication she can deceive the audience of followers, affecting their consumption choices and habits. This is likely to be fostered by two main factors that depend on the design of the social media user's journey.

First of all, influencer marketing is more difficult to recognise because of the media used. Indeed, context plays an important role in making the consumer aware of marketing intent. When the consumer is in front of the TV watching an advertising break during her favourite programme or is looking at a billboard she can easily identify that she is staring at an advertisement. In contrast, social media blurs the boundaries between private and public life, between personal and

\footnotetext{
*Rossana Ducato (rossana.ducato@uclouvain.be) is a postdoctoral researcher in Law at UCLouvain and Université Saint- Louis - Bruxelles. http://www.rosels.eu/member/rossana-ducato/. Her research is supported by the Brussels-Capital Region - INNOVIRIS. The author would like to thank Mrs. Daria Onitiu for her helpful advice and comments on the German case law examined in this paper. The author, however, bears full responsibility for the Chapter.
} 
commercial activity: sponsored endorsements by SMIs end up being absorbed and diluted in the constant flow of posts published, popping up among contents narrating events of everyday life.

Second, the consumer may not recognise that she is being exposed to an advertisement because of the nature of the individual conveying the message: a trusted peer. Especially in the case of bloggers or vloggers, who have reached their popularity thanks to their activity of reviewing products or creating tutorials, the SMI is perceived as an independent third party who shares an opinion based on her personal experience.

Considering these structural factors, the consumer can be misled by the activity of a SMI if the relevant information about the commercial nature of the communication is kept hidden from its recipients. If user-generated content (UGC) is presented as a simple post or tutorial the consumer might not activate the self-defence mechanisms that usually help her to critically filter the content of an advertisement.

The existing legal framework can certainly offer some responses to tackle the issue of the transparency of commercial communications. The issue is not entirely new, but it does indeed pose additional challenges to European law and some of its traditional categories, such as "trader" or "commercial practice".

The aim of this paper is to navigate such legal uncertainties and shed some light on the application of the European consumer and media laws to the SMI phenomenon, focusing in particular on information obligations.

The structure of the paper is as follows. After offering a preliminary overview of the main actors involved in influencer marketing and corresponding relationships in Section II, the paper will critically reconstruct what the information duties are for SMIs, paying attention to the first interpretations and cases occurring at national level (Section III). Then the contribution will address the role of social media platforms in influencer marketing. It will argue arguing for subjecting such online intermediaries to specific duties in designing their web-infrastructure in such a way as to embed legal principles in the online environment (Section IV). Finally, the paper concludes in Section V, highlighting suggestions and proposals for enhancing the protection of online consumers and the transparency of influencers' practices.

\section{KEYWORDS}

Influencers - consumer protection - unfair commercial practice - audiovisual media service directive - platforms - information duties - design duties - transparency 


\section{Introduction}

Social media influencers (SMI) have become familiar figures over the last few years. We visit their profiles, watch their "stories", retweet, like and share their posts. Bloggers, vloggers, Instagrammers, Facebook Famous and Musers are terms that have entered our daily vocabularies and such people have established themselves as new celebrities. 1

However, the influencer phenomenon is not just about amusement. Considering the authority and reputation gained in the Internet arena, the value of SMIs - as a new generation of testimonials - has been promptly understood by brands and advertising professionals. A large part of marketing investment is now dedicated to securing the endorsement of influencers, and methods for identifying the relevant or emerging influencers in a given area have even been patented.2

Influencer marketing is not prohibited a priori by law but has raised several concerns from a legal standpoint. When an SMI endorses a particular brand or product without clearly disclosing the marketing purpose of that communication she can deceive the audience of followers, affecting their consumption choices and habits. This is likely to be fostered by two main factors that depend on the design of the social media user's journey. First of all, influencer marketing is more difficult to recognise because of the media used. Indeed, context plays an important role in making the consumer aware of marketing intent. When the consumer is in front of the TV watching an advertising break during her favourite programme or is looking at a billboard she can easily identify that she is staring at an advertisement. In contrast, social media blurs the boundaries between private and public life, between personal and commercial activity: sponsored endorsements by SMIs end up being absorbed and diluted in the constant flow of posts published, popping up among contents narrating events of everyday life. Second, the consumer may not recognise that she is being exposed to an advertisement because of the nature of the individual conveying the message: a trusted peer. Especially in the case of bloggers or vloggers, who have reached their popularity thanks to their activity of reviewing products or creating

\footnotetext{
${ }^{1}$ As the average reader might not be familiar with all of these, by 'blogger' we mean an individual who regularly writes for a blog (i.e. a website that contains personal opinions, comments, and visual or audio contents). The 'vlogger' is similar to the previous figure but the content is provided in the form of short videos uploaded on social media channels like YouTube. Meanwhile, the Instagrammers, Facebook Famous and Musers are named after the social media platforms used respectively, Instagram (www.instagram.com), Facebook (www.facebook.com), and Musical.ly (now, TikTok, www.tiktok.com). In these cases the content can be video, audio, graphical, textual or a combination.

${ }^{2}$ Wei Peng and Tong Sun, Method and system for identifying a key influencer in social media utilizing topic modeling and social diffusion analysis (Google Patents 2012); Hernan A Makse and Flaviano Morone, Method to maximize message spreading in social networks and find the most influential people in social media (Google Patents 2016).
} 
tutorials, the SMI is perceived as an independent third party who shares an opinion based on her personal experience.

Considering these structural factors, the consumer can be misled by the activity of a SMI if the relevant information about the commercial nature of the communication is kept hidden from its recipients. If user-generated content (UGC) is presented as a simple post or tutorial the consumer might not activate the self-defence mechanisms that usually help her to critically filter the content of an advertisement.3

The existing legal framework can certainly offer some responses to tackle the issue of the transparency of commercial communications. The issue is not entirely new "wordof-mouth 2.0" 4 does indeed pose additional challenges to European law and some of its traditional categories, such as "trader" or "commercial practice".

The aim of this paper is to navigate such legal uncertainties and shed some light on the application of the European consumer and media laws to the SMI phenomenon, focusing in particular on information obligations. 5

The structure of the paper is as follows. After offering a preliminary overview of the main actors involved in influencer marketing and corresponding relationships in Section II, the paper will critically reconstruct what the information duties are for SMIs, paying attention to the first interpretations and cases occurring at national level (Section III). Then the contribution will address the role of social media platforms in influencer marketing. It will argue arguing for subjecting such online intermediaries to specific duties in designing their web-infrastructure in such a way as to embed legal principles in the online environment (Section IV). Finally, the paper concludes in Section V, highlighting suggestions and proposals for enhancing the protection of online consumers and the transparency of influencers' practices.

\section{The fellowship of the influencer}

Influencer marketing involves the creation and dissemination of sponsored content via SMIs. Such a new trend in the online advertising field usually sees the involvement of four different actors: 1) A brand that tries to optimise its advertising strategy thanks to the social authoritativeness of the influencer. 2) An SMI who creates the sponsored content and embeds it into her narrative on a social media platform. 3) The provider of a social

\footnotetext{
3 On the misleading effect of covert advertising, see D'Antonio Virgilio, 'La comunicazione commerciale' in Salvatore Sica and Vincenzo Zeno-Zencovich (eds), Manuale di diritto dell'informazione e della comunicazione (CEDAM 2015), 235.

4 "Word-of-mouth" can be described as an informal system of recommendations, where news, advices (and in many cases, also rumors) are passed orally from one person to another.

${ }^{5}$ The analysis is concentrated on influencer marketing. Therefore, native advertising, advertorials and social proof are out of the scope of the paper.
} 
media platform that allows the creation and dissemination of UGC and interaction among its users. 4) The follower, i.e. the user of the platform and ultimate recipient of the marketing communication.

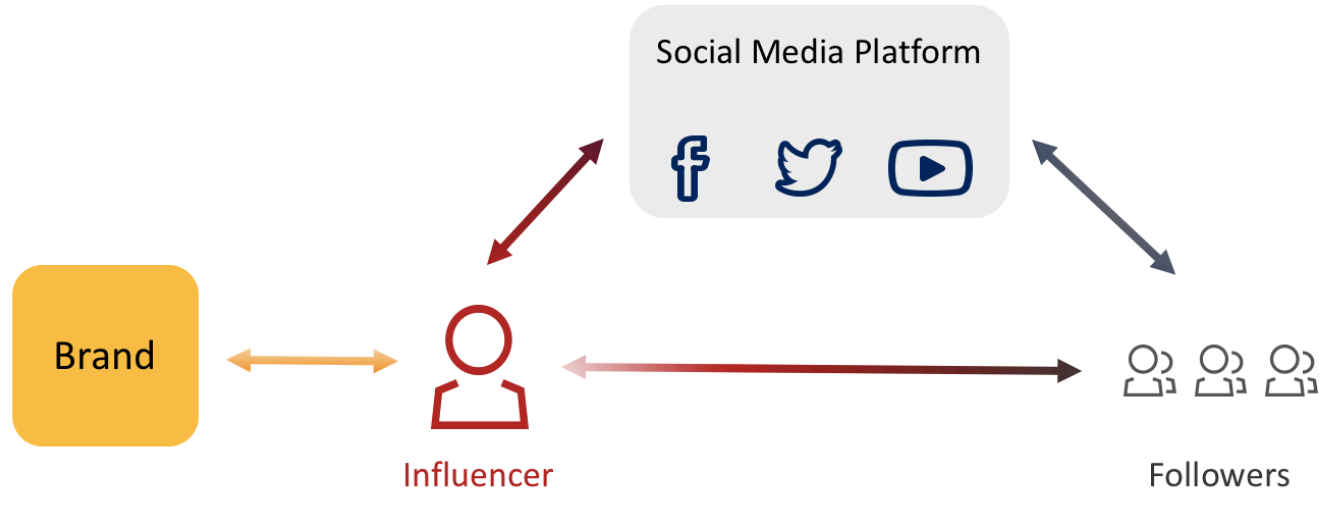

Figure 1. Structure of the influencer marketing relationships

In current practice there may be possible variances to the previous scheme. 1) The influencer marketing structure can include an additional actor, i.e. the agency of the influencer. Such a figure is an intermediary generally used by celebrities and big influencers, while this is less common in the case of micro- or nano-influencers. 2) In contrast, there will be only three actors if the SMI promotes her own products and brand.6

In the basic scenario represented in Figure 1, the relationship between the brand and the influencer is usually governed by an agreement which establishes the conditions of the partnership. In such a document the brand determines to what extent it exercises some forms of editorial control over the influencer's UGC, i.e. the type, amounts and frequency of content to create, the social media channel to be used, the eventual guidelines to follow for conveying the brand message or philosophy or, ultimately, what to write. While, as regards the counter-performance, this may consist of monetary payment or the provision of free products to the SMIs. Such agreements are atypical contracts that cannot be traced back to a single scheme. On the one hand, they entail assignment to the SMI of the tasks of creating and disseminating advertising content on a social media channel. In these cases, the SMI can act as self-employed or an employee of the brand.7 On the other hand, it must be noted that the content, the qualification of influencer marketing agreements, and therefore their discipline, may depend on the platform used by the SMI. Where the performance of the influencer consists of publishing pictures wearing or showing particular

\footnotetext{
${ }^{6}$ On the structure of influencer marketing, similarly Jan Trzaskowski, 'Identifying the Commercial Nature of 'Influencer Marketing' on the Internet' (2018) 65 Scandinavian Studies in Law 50.

${ }^{7}$ Ibid., 86.
} 
brands (such as in the case of Instagram), the kind of agreement concluded shares some common features with sponsoring and endorsement contracts. Here a company uses the testimonial's popularity to increase the visibility of its brand, without performing a proper réclame aimed at directly selling a product or service. 8 Meanwhile, in the case of bloggers or vloggers, the SMI does not simply show the product but talks about it in positive terms. This practice is more similar to the content of advertorials, a form of advertising that is presented as newspaper articles or third-party informative services. 9

However, reality is even more nuanced: despite the advertising activity of the SMI there might be no agreement with the brand at all. A growing trend among influencers is in fact to promote some companies, by adding a link to them or overly exalting the qualities of a product, not to actually favour that particular brand but to attract future sponsoring opportunities. In more extreme cases the practice of "fake advertising", where the content is artfully camouflaged to appear as a paid disclosure, is also taking hold among aspiring influencers as a self-promotion strategy. 10

The relationship between a brand and SMIs can also be mediated by a social media platform, its contracts and its digital architecture: Facebook, for example, enacted "Branded Content Policies"11 (published in 2016 and latest revised in June 2018) linked to the "Branded Content Tool"12. The latter is an instrument that allows mentioning ("tagging") a business partner. In this way companies may gain direct insights regarding the level of engagement with content, it being possible for them to visualise the post's metrics. The platform manages and controls the flow of information about the interactions of different users with sponsored content. Therefore, Facebook's terms of service also affect the downstream relationships between influencers and brands.

\footnotetext{
${ }^{8}$ V. Falce, 'I contratti di sponsorizzazione', in Alberto Maria Gambino (ed), I contratti di pubblicità e sponsorizzazione (Giappichelli 2012), 53. See also, Massimo Bianca, I contratti di sponsorizzazione (Maggioli, 1990); Alberto Musso, 'La sponsorizzazione come contratto commerciale' (2013) 2 Aedon 1127.

${ }^{9}$ Andrea Stazi, 'I contratti di diffusione pubblicitaria non tabellare', in Alberto Maria Gambino (ed), I contratti di pubblicità e sponsorizzazione (Giappichelli 2012), 33-35; Rhonda Brown, 'Ad hoc access: The regulation of editorial advertising on television and radio' (1988) 6 Yale Law \& Policy Review 449. See also, Amy Ralph Mudge and Randal M. Shaheen, Native advertising, influencers and endorsements: Where is the line between integrated content and deceptively formatted advertising? (2017) 21 Journal of Internet Law 1.

https://www.theatlantic.com/technology/archive/2018/12/influencers-are-faking-brand-

${ }^{11}$ https://www.facebook.com/policies/brandedcontent. For branded content, Facebook means "a creator or publisher's content that features or is influenced by a business partner for an exchange of value". https://www.facebook.com/policies/brandedcontent.

${ }^{12}$ The "Branded Content Tool" appears to be the only way to publish sponsored content (or "branded content" as labelled by the platform) on Facebook, while for Instagram (which is owned by Facebook) such a limitation does not apply. The Branded Content Policies, in fact, state: "Branded content may only be posted by Facebook Pages and profiles with access to the branded content tool. All Instagram accounts can post branded content" (https://www.facebook.com/policies/brandedcontent).
} 
Finally, the interplay between an influencer and her followers is also mediated by social media platforms, their terms and policies. Any violation of the latter may result in a private sanction (removal of content, suspension or termination of the account) being enforced by the platform.13 In addition to some bans generally established by social media in order to maintain a safe and respectful environment (prohibition against publishing illegal, discriminatory, violent content, etc.), some platforms have issued specific provisions or policies with reference to the publication of sponsored posts by influencers. Facebook, for example, establishes that: "adverts must not contain deceptive, false or misleading content, including deceptive claims, offers or business practices"14 (which can be read as including the deceptive practice of hiding a commercial link with the brand). It also states that users must "[c]omply with all applicable laws and regulations, including by ensuring that [the user] provides all necessary disclosures to people using Facebook or Instagram, such as any disclosures needed to indicate the commercial nature of content posted by [the user]"15.

Having outlined the different actors involved in the practice of influencer marketing, and their respective relationships, we can now move to exploring the corresponding obligations and responsibilities with reference to the transparency of commercial communication.

\section{The two towers: mandated disclosures of influencers between unfair commercial practices and e-commerce}

The practice of SMIs can become problematic when it clashes with the duties imposed by the information paradigm. The latter is the key theoretical framework underlying several consumer protection instruments at European Union level.16 The fundamental

\footnotetext{
${ }^{13}$ On the private ordering established by platforms, such as Facebook and YouTube, for advertising content, see Jan Trzaskowski, 'User-generated marketing-legal implications when word-of-mouth goes viral' (2011) 19 International Journal of Law and Information Technology 348.
}

14 Point 4(13). Advertising Policies,

https://www.facebook.com/policies/ads/prohibited_content/misleading_or_false_content.

${ }^{15}$ https://www.facebook.com/policies/brandedcontent.

${ }^{16}$ Stefan Grundmann, Wolfgang Kerber and Stephen Weatherill, Party autonomy and the role of information in the internal market (Walter de Gruyter 2001); Udo Reifner and Isabel Herwig, 'Consumer education and information rights in financial services' (2003) 12 Information \& Communications Technology Law 125; Geraint Howells, 'The potential and limits of consumer empowerment by information' (2005) 32 Journal of Law and Society 349; G Howells, A Janssen and R Schulze, Information rights and obligations: a challenge for party autonomy and transactional fairness (Ashgate 2005); Thomas Wilhelmsson, European rules on pre-contractual information duties? (Springer 2005); Thomas Wilhelmsson and Christian Twigg-Flesner, 'Pre-contractual information duties in the acquis communautaire' (2006) 2 European Review of Contract Law 441; Hans Schulte-Nölke, 'EC Law on the Formation of Contractfrom the Common Frame of Reference to the "Blue Button" (2007) 3 European Review of Contract 
assumption of this paradigm is that only if the consumer is informed in a transparent way will she be able to make a rational decision and effectively exercise her private autonomy. According to this perspective the reduction of information asymmetries aims at rebalancing the ontological situation of inequality between the trader and the consumer, thus enhancing the bargaining power of the weak party. At the same time, information is traditionally considered as a means of supporting market transparency and, therefore, of preventing market inefficiencies. 17

Mandated disclosures are a pillar of the information paradigm and constitute a widespread policy technique in the consumer protection framework.18 Within European consumer legislation information duties manifest themselves in three different shapes:19 1) As a positive duty to provide a set of information expressly listed in the law;20 2) As an implicit obligation for the trader in the sale of consumer good;21 and 3) As material omissions reflective of unfair commercial practices (misleading omissions). 22

It is precisely the latter instance of the information paradigm that is relevant in light of the opaque practices adopted by some SMIs. The Unfair Commercial Practices Directive (hereinafter "UCPD") is indeed the most prominent legislative tool that could allow us to

Law 332; Elizabeth Hall, Geraint Howells and Jonathon Watson, 'The Consumer Rights Directive-An Assessment of its Contribution to the Development of European Consumer Contract Law' (2012) 8 European Review of Contract Law 139; N Reich and HW Micklitz, 'Economic Law, Consumer Interests and EU Integration' in N Reich (ed), European Consumer Law (Inersentia 2014); Marco Loos, 'Transparency of standard terms under the Unfair Contract Terms Directive and the proposal for a common European sales law' (2015) 23 European Review of Private Law 179; Ilse Samoy and Marco Loos, Information and notification duties (Intersentia 2015); Christoph Busch, 'The future of precontractual information duties: from behavioural insights to big data' in Christian Twigg-Flesner (ed), Research Handbook on EU Consumer and Contract Law (Edward Elgar 2016); David Kästle-Lamparter, 'Precontractual information duties' in N. Jansen and R. Zimmermann (eds), Commentaries on European Contract Laws (Oxford University Press 2018).

${ }^{17}$ As pointed out in the seminal works of George A Akerlof, 'The market for "lemons": Quality uncertainty and the market mechanism', Uncertainty in economics (Elsevier 1978); Michael Rothschild and Joseph Stiglitz, 'Equilibrium in competitive insurance markets: An essay on the economics of imperfect information', Uncertainty in economics (Elsevier 1978).

${ }^{18}$ Despite a growing body of literature has exposed the limitations of such a paradigm. Ex multis, Omri Ben-Shahar and Carl E Schneider, More Than You Wanted to Know. The Failure of Mandated Disclosure (Princeton University Press 2014).

${ }^{19}$ Kästle-Lamparter, 'Pre-contractual information duties', 394 ff.

${ }^{20}$ See, for example, Articles 5 and 6 of Directive 2011/83/EU on consumer rights [2011] OJ L304/64.

${ }^{21}$ Where the seller cannot be found liable if she has drawn the attention of the consumer toward some characteristics of the good that might have otherwise considered as lack of conformity. See Article 2(3) of Directive 1999/44/EC on certain aspects of the sale of consumer goods and associated guarantees [1999] OJ L171/12.

${ }^{22}$ Article 7 of Directive 2005/29/EC concerning unfair business-to-consumer commercial practices in the internal market ('Unfair Commercial Practices Directive') [2005] OJ L 149/22. 
frame the issue of misleading advertising in influencer practices.23 The Directive, in fact, obliges a trader to disclose the commercial nature of her practice if it is not immediately recognisable from the context. Such an information duty can be reconstructed a contrario from Article 7(2) UCPD, which considers lack of disclosure about the commercial intent of a commercial practice a misleading omission within the meaning of Article 7(1) UCPD (i.e. the omission of relevant transactional information which is able to affect the decisionmaking process of the weak party).24 The Directive does not provide any specific indication about the means that have to be used for the information notice, 25 but it does introduce a flexible parameter that takes into account the eventual constraints imposed by the medium of communication. 26

\footnotetext{
${ }^{23}$ See, Trzaskowski, 'User-generated marketing-legal implications when word-of-mouth goes viral'; Damian Clifford and Valerie Verdoodt, 'Integrative advertising: the marketing'dark side'or merely the emperor's new clothes?' (2017) 8 European Journal of Law and Technology; Trzaskowski, 'Identifying the Commercial Nature of 'Influencer Marketing' on the Internet'; Christine Riefa and Laura Clausen, 'Towards Fairness in Digital Influencers' Marketing Practices' (2019) 8 Journal of European Consumer and Market Law 64.
}

${ }^{24}$ Article 7(1) UCPD. More specifically, the lack of information has to induce or be likely to induce the consumer to take a decision that she would have not taken otherwise. This "misleading assessment" under the UCPD has to be conducted having in mind the "average consumer", the abstract model of the "reasonably well-informed and reasonably observant and circumspect", as elaborated by the ECJ since the leading case, Case C-210/96 Gut Springenheide and Rudolf Tusky v. Oberkreisdirektor des Kreises Steinfurt [1998] ECR I-4657. For a critical assessment of the notion of the average consumer in EU Law, see R Incardona and C Poncibò, 'The average consumer, the unfair commercial practices directive, and the cognitive revolution' (2007) 30 J Consumer Policy 21; Vanessa Mak, 'Standards of protection: In search of the 'average consumer' of EU law in the Proposal for a Consumer Rights Directive' (2011) 19 European review of private law 25; Vanessa Mak, 'The 'average consumer' of EU law in domestic and European litigation' in Dorota Leczykiewicz and Stephen Weatherill (eds) The Involvement of EU Law in Private Law Relationships (Studies of the Oxford Institute of European and Comparative Law, Hart Publishing, Oxford 2013); Anne-Lise Sibony, 'Can EU consumer law benefit from behavioural insights? An analysis of the unfair practices directive' (2014) 22 European Review of Private Law 901; Kai Purnhagen, 'Regulatory Validity' in Hans-W. Micklitz, Anne-Lise Sibony and Fabrizio Esposito (eds) Research Methods in Consumer Law: A Handbook (Edward Elgar, 2018). The ECJ interpretation was embedded in recital $18 \mathrm{UCPD}$, which also clearly points out that "the average consumer test is not a statistical test". The assessment is a normative one that has to be performed by national courts and authorities on a case-by-case basis.

25 See, Case C-562/15 Carrefour Hypermarchés SAS v. ITM Alimentaire International SASU [2017] ECLI:EU:C:2017:95, § 37.

${ }^{26}$ The role and limitations imposed by the medium used for the communication of information are adequately balanced in the system of the Directive. The time and space constraints of certain medium - and social media are no exception - can constitute a serious obstacle in providing the information referred to by Article 7 UCPD. However, such hurdles do not exempt the trader from the duty to provide the disclosure. On the contrary, the constraints have to be balanced in light of the alternative measures that the trader has put in place to adequately inform the consumer. In other words, the limitations imposed by the medium do not have to be interpreted for evaluating the an of the disclosure but eventually to assess its quomodo. As indirectly confirmed by Trzaskowski, 'Identifying the Commercial Nature of 'Influencer Marketing' on the Internet', 85. 
The provision of Article 7(2) UCPD could potentially apply in the case of SMIs. However, three preliminary interpretative questions have to be untangled, considering that the scope of application of the Directive is restricted to business-to-consumer relationships. First, is the SMI a trader? Second, if yes, by posting sponsored content, does the SMI perform a commercial practice within the meaning of the UCPD? Third, is the influencer's practice likely to distort the transactional behaviour of the consumer?

The UCPD can come into play only if the SMI falls within the notion of a "trader". The latter is defined as "any natural or legal person who [...] is acting for purposes relating to his trade, business, craft or profession and anyone acting in the name of or on behalf of a trader"27. An SMI is likely to qualify as a trader if the advertising activity is part of her business, e.g. the influencer publicises her own brand or line of products on social media. Similarly, if an SMI acts on behalf of the brand, because of an underlying agreement, the influencer can be classified as a trader.

However, such a qualification can be more difficult to assess in other circumstances, like in the case of bloggers - who generate an advertising effect as an externality of their activity of independent reviews - or when an SMI acts in exchange for prizes or free products.28 In Kamenova, where the CJEU was called to interpret the notions of "trader" and "commercial practices" in the case of a natural person placing eight selling advertisements on an e-commerce website, the Court provided some principles for guiding case-by-case evaluation.29 The decision was issued in the context of distance contracts, nevertheless some of the criteria there enumerated could be analogically used in the context of influencer marketing. Among the elements for proceeding with the identification of a subject as a trader, the Court included: the level of organisation of the activity, the legal status of the individual and the connection of the online practice with her commercial or professional activity, the taxation of the activity, and the receipt of remuneration of incentives of any kind.30

If an influencer qualifies as a trader it is then necessary to ascertain whether her activity can be considered a "commercial practice" within the meaning of the UCPD.31

\footnotetext{
${ }^{27}$ Article 2(b) UCPD.

${ }^{28}$ As noted by Riefa and Clausen, 'Towards Fairness in Digital Influencers' Marketing Practices'.

${ }^{29}$ Case C-105/2017 Komisia za zashtita na potrebitelite v. Evelina Kamenova [2018] ECLI:EU:C:2018:808. In this case the ECJ had to interpret the notion of trader in relation to an individual who posted eight advertisements for the sale of new and second-hand products on an e-commerce platform. For a comment, see Rossana Ducato, 'La nozione di professionista al vaglio della Corte di Giustizia dell'Unione Europea (commento a Corte giustizia Unione Europea Sez. V, 4 ottobre 2018, C-105/17' in Teresa Pasquino (ed), Antologia di casi giurisprudenziali (Giappichelli 2019).

${ }^{30}$ Paraphrasing the list provided in Case C-105/2017, §38.

${ }^{31}$ Commercial practices are defined in Article 2(d) UCPD as: "any act, omission, course of conduct or representation, commercial communication including advertising and marketing, by a trader, directly connected with the promotion, sale or supply of a product to consumers".
} 
Again, if the SMI is promoting or selling her own products to consumers there are few doubts that her activity can be considered a commercial practice. In contrast, the boundaries are less clear when the influencer promotes third-party products or services while acting as self-employed. In the latter case some authors have doubted that the influencer's activity could be captured by the UCPD. 32

Such an argument has been advanced on the basis of the obiter dicta in RvLS.33 In that case a competitor contested the publication by RvLS (a German advertising magazine) of two sponsored pieces of editorial content without the proper "advertisement" label, as required by a German provision regulating the printing press ( $\$ 10$ of the Landespressegesetz Baden-Württemberg). In stating that German law can discipline the activity of a publisher more restrictively (in this case, by establishing the use of a specific word to label content financed by third parties), the CJEU denied the possibility of classifying the publication of sponsored articles in a newspaper as a "commercial practice" performed by the publisher.34 If there is a commercial practice, the latter is ultimately put in place by the sponsors of the article and not by the publisher itself: "given its ratione personae scope, Directive 2005/29 is indeed intended to protect consumers of products and services of those same undertakings and their legitimate competitors". 35 Continuing in this line of reasoning, the Court further observed that the editorial content could have not significantly distorted the behaviour of consumers and encouraged them to buy the RvLS newspaper.

According to Trzaskowski, if we apply the same conclusions to the situation where the activity of SMIs resembles editorial media content, we could maintain that such a practice is not covered by the definition of commercial practices under the UCPD: the SMI promotes a third-party product with few chances to distort the economic behaviour of consumers in relation to the influencer's services.36 In such cases the Directive shall not

\footnotetext{
${ }^{32}$ Trzaskowski, 'Identifying the Commercial Nature of 'Influencer Marketing' on the Internet'.

33 Case C-391/12 RLvS Verlagsgesellschaft mbH v. Stuttgarter Wochenblatt GmbH [2013] ECLI:EU:C:2013:669.

${ }^{34}$ In that controversy the ECJ was called to decide upon the scope of application of the UCPD (in particular, point 11 of Annex I) in relation to the German national law provision compelling publishers to explicitly label with the term "advertisement" an article remunerated by a third party ( $\$ 10$ of the Landespressegesetz Baden-Württemberg of 14 January 1964). The Court established that the UCPD "may not be relied on as against newspaper publishers, with the result that, in those circumstances, that directive must be interpreted as not precluding the application of a national provision under which those publishers are required to identify specifically, in this case through the use of the term 'advertisement' ('Anzeige'), any publication in their periodicals for which they receive remuneration, unless it is already evident from the arrangement and layout of the publication that it is an advertisement" (deciding against the Opinion of the Advocate General Wathelet, delivered on 11 July 2013, ECLI:EU:C:2013:468).

${ }^{35}$ Case C-391/12, § 40.

${ }^{36}$ Trzaskowski, 'Identifying the Commercial Nature of 'Influencer Marketing' on the Internet', 88.
} 
apply. However, as noticed by the same author, it is not entirely clear whether the RvLS principles can be analogically applied to other cases beyond the publication of editorial content in newspapers.37

Nevertheless, the ECJ judgement confirms two important points. First, if the SMI acts as a longa manus of the brand ("on behalf of") she participates in the commercial activity of the undertaking. 38 So, she will perform a commercial practice in the meaning of the UCPD as long as she falls within the notion of a trader. Second, the primary responsibility for unfair practices will lie with the trader who benefits from the SMI's promotion.39 The undertaking whose products are sponsored should therefore ensure via contractual means - that the influencer discloses the advertising nature of the post when she shares it with her followers.

Finally, can the commercial practice of an influencer, consisting of promoting thirdparty products through social media platforms, affect the transactional decision-making processes of consumers? According to Article 7(2) UCPD a misleading omission must consist of a material distortion, meaning that it has to induce the "average consumer" to take a decision that she would not otherwise have taken. To this end mere persuasion or negligible influences on consumers do not have to be taken into account.40 Riefa and Clausen have expressed serious doubts about the possibility of demonstrating a causal link between the actions of a trader and the transactional behaviour of a consumer in the context of influencer marketing, since several different factors may affect the purchasing motivation of a consumer in practice. 41 This can indeed be a difficult issue to untangle but two aspects must be underlined.

On the one hand, the first empirical studies in this sector are demonstrating that social media endorsement influences users' transactional decision. 42 Confirmation of this

\footnotetext{
${ }^{37}$ As noticed by ibid. Furthermore, blogs and posts on social media can hardly fit with the definition of editorial content (point 11, Annex I, UCPD). Cf. Gfk Consortium, Behavioural Study on Advertising and Marketing Practices in Online Social Media. Annex 1.5 Legal Assessment of Problematic Practices, 2018), 15.

38 See Case C-391/12, § 38.

39 Similarly to what was observed for agents and advertising services, see Geraint Howells, Hans-W Micklitz and Thomas Wilhelmsson, European fair trading law: The unfair commercial practices directive (Routledge 2006), 68.

40 As stated at Recital 6 UCPD: "this Directive does not affect accepted advertising and marketing practices, such as legitimate product placement, brand differentiation or the offering of incentives which may legitimately affect consumers' perceptions of products and influence their behaviour without impairing the consumer's ability to make an informed decision”.

${ }^{41}$ Riefa and Clausen, 'Towards Fairness in Digital Influencers' Marketing Practices', 67.

${ }^{42}$ See the results of the questionnaire launched by the UK Competition and Market Authority in 2018, https://www.gov.uk/cma-cases/social-media-endorsements. Furthermore, even if an endorsement does not affect the choice of the consumer at the moment of exposure, a positive image and repetition of the advertisement can nevertheless influence the purchase decision at a later stage. Gfk Consortium,
} 
can also be drawn from the infamous Fyre affaire, where a promotion carried out by top influencers was key to selling the event.43 In one of the several lawsuits following the fiasco of the promised luxury musical festival in the Bahamas, consumers alleged that the influencers' posts on Instagram were perceived as authentic and genuine personal experiences, and that SMIs "gave the impression that the guest list was full of the Social Elite and other celebrities".44

On the other hand, we have to bear in mind that the UCPD does not require proof of a strictu sensu causality:45 the evaluation is a normative assessment and the legal interpreter does not have to verify actual distortion of consumer behaviour but the potential of the trader's practice to make it happen.46 Furthermore, in the European framework the notion of a consumer's transactional decision is formulated and interpreted in very broad terms, also encompassing the acts preparatory to a purchase, such as the decision to enter a shop. 47 Therefore, it is necessary to look at the deceptive nature of the omission objectively and consider, with prognostic judgement, whether the omission could mislead a reasonably observant and circumspect consumer. In the case of Instagram, for example, if any mention of commercial intent is completely missing, by clicking on the "@” or "\#” referring to the brand the follower is likely to be redirected unawares on a company page or e-commerce website. Her transactional behaviour could therefore be inevitably conditioned.

In any case, even if we could not rely on Article 7(2) UCPD, because the activity of the influencer cannot be classified as a commercial practice able to influence a consumer's transactional decision, point 22 of Annex I UCPD can constitute a normative reference able to capture many of the current deceptive practices of influencers. 48 Point 22, included

Behavioural Study on Advertising and Marketing Practices in Online Social Media, 2018), 40. See, in particular, the bibliography cited in note 22 .

${ }^{43}$ Cf. Catalina Goanta, 'Consumers on fyre: Influencer marketing and recent reactions of the United States Federal Trade Commission' (2017) 2017 Transatlantic Antitrust and IPR Developments 35.

${ }^{44}$ Class action complaint field to the Superior Court of California, County of Los Angeles, 2 May 2017, available here: https://www.manatt.com/Manatt/media/Media/PDF/Newsletters/Advertising\%20Law/Chinery-vFyre-Media,-Inc.pdf

${ }^{45}$ Howells, Micklitz and Wilhelmsson, European fair trading law: The unfair commercial practices directive, 110.

${ }^{46}$ Ibid, 109. Hans-Wolfgang Micklitz, Norbert Reich and Peter Rott, Understanding EU consumer law (Intersentia 2009), 87.

${ }^{47}$ Case C-281/12 Trento Sviluppo srl, Centrale Adriatica Soc. coop. arl v. Autorità Garante della Concorrenza e del Mercato [2013] ECLI:EU:C:2013:859, §§ 35-36. As underlined also by Trzaskowski, 'Identifying the Commercial Nature of 'Influencer Marketing' on the Internet', 85.

${ }^{48}$ See, for instance, Consortium, Behavioural Study on Advertising and Marketing Practices in Online Social Media. Annex 1.5 Legal Assessment of Problematic Practices; Sophie C Boerman and others, 'Sponsored Blog 
in the list of practices that are considered unfair under all circumstances, prohibits the action of "falsely claiming or creating the impression that the trader is not acting for purposes relating to his trade, business, craft or profession, or falsely representing oneself as a consumer". Such a provision, read in combination with Article 7(2) UCPD, requires the trader (the SMI, in our case) to disclose her legal nature and the commercial intent of her practices. 49

On a residual basis we must also consider a further option. A blog and the account of an influencer can be considered as an information society service in itself and subject to e-commerce transparency requirements.50 In literature there are few doubts about the classification of personal blogs as information society services: even if they are not actively remunerated by the people accessing them, blogs represent an "economic activity" 51 if they generate direct or indirect economic benefits for the provider. Similar considerations may apply to the influencer's profile if the latter is supported by advertising or if the activity might give rise to reputational gain.52

Given this premise, influencers performing commercial communication through blogs or their social media accounts will have to ensure that commercial communication is clearly identifiable as such (Article 6 E-Commerce Directive), unless the communication is "compiled in an independent manner, particularly when this is without financial consideration".53

The reference to the E-Commerce Directive could have the advantage of having a broader scope of application compared to the UCPD, since indirect promotions of a thirdparty image or product would be covered.54 Thus, it could help overcome possible gaps in protection for consumers raised with reference to the possible outcomes of the RvLS decision.

The applicability of the UCPD and e-commerce framework has found some

Content: What Do the Regulations Say: And What Do Bloggers Say' (2018) 9 J Intell Prop Info Tech \& Elec Com L 146; Riefa and Clausen, 'Towards Fairness in Digital Influencers' Marketing Practices'.

${ }^{49}$ EC Commission, Guidance on the implementation/application of Directive 2005/29/EC on unfair commercial practices, Accompanying the document Communication from the Commission to the European Parliament, the Council, the European Economic and Social Committee and the Committee of the Regions "A Comprehensive Approach to Stimulating Cross- border e-Commerce for Europe's citizens and businesses", SWD(2016) 163 final, 121.

${ }^{50}$ Directive 2000/31/EC on certain legal aspects of information society services, in particular electronic commerce, in the Internal Market ('Directive on electronic commerce') OJ L178/1. On the application of the e-commerce framework to influencers, see Trzaskowski, 'Identifying the Commercial Nature of 'Influencer Marketing'on the Internet', 92.

${ }^{51}$ As required by Recital 18 of the e-commerce Directive.

${ }^{52}$ Jaani Riordan, The liability of internet intermediaries (Oxford University Press 2016), 389-390.

${ }^{53}$ Article 2(f) e-commerce Directive.

${ }^{54}$ Trzaskowski, 'Identifying the Commercial Nature of 'Influencer Marketing' on the Internet', 91. 
preliminary confirmations at national level. This is the case for actions undertaken by the Italian Competition and Market Authority ("Autorità Garante della Concorrenza e del Mercato", hereinafter AGCM) and a series of decisions issued by German courts. In the next paragraphs such experiences will be presented in order to highlight convergences and divergences in the influencer marketing phenomenon in the two legal systems.

\subsection{The Italian way}

\subsubsection{The AGCM's action}

The Italian experience represents an interesting example to start with, since it registered the first intervention of an authority in the field of influencer marketing. In 2017 the activity of some influencers was under the scrutiny of AGCM, the independent administrative authority with competence over unfair commercial practices, and misleading and unlawful comparative advertising. 55

The AGCM recognises that influencer marketing has become a "powerful form of advertising" 56 and has warned against the risk that endorsements given by SMIs may materialise in hidden advertising in the absence of adequate disclosures about the marketing purpose of a communication. In the view of the authority there are some structural factors that are contributing to the deceiving effect:

"influencers are able to establish a relationship with consumer-followers, who perceive such communications as advice deriving from personal experience and not as advertising communication. Often, the images with highlighted brands, posted on the personal profile of the character, alternate with others where no brand appears, in a flow of images that give the impression of a narrative of one's everyday life. The images, in fact, sometimes represent a domestic environment and are made with photographic techniques that are not sought after; other times, the types of images, the poses of the characters and the environment take on the style of a photographic set. The evidence given to brands can vary in intensity and modality, as the types of posts and characters are very heterogeneous. In some cases, the names of the brands are mentioned in the hashtags of the posts, in other cases, they are instead in evidence in the image. The post can be accompanied by emphatic comments on the product". 57

Such a situation of opaqueness can have an impact on consumer choices if the commercial agreement between the influencer and the brand is not brought to the

\footnotetext{
${ }^{55}$ http://en.agcm.it/en/

56 AGCM, Relazione annuale sull'attività svolta, http://www.agcm.it/dotcmsDOC/relazioniannuali/relazioneannuale2017/Relazione annuale_2018.pdf, Chapter 3, 237.

57 AGCM, Comunicato stampa, "Antitrust su Influencer Marketing: la pubblicità deve essere sempre trasparente”, 24 July 2017, http://www.agcm.it/media/comunicati-stampa/2017/7/alias-8853.
} 
attention of the follower.

The AGCM recalled that the prohibition of hidden advertising has a general scope and also applies in cases of commercial communication spread via social networks.58 Hence, if the SMI lets her followers believe she is acting in a spontaneous and disinterested manner, while in reality she is sponsoring a brand, such a practice is likely to be in contrast with the provisions related to misleading omissions enshrined in the Italian Consumer Protection Code (Article 22).59

Therefore, between 2017 and 2018, the AGMC launched two actions of moral suasion to ensure, with the collaboration of companies and professionals, the removal of this potentially unfair practice.60 The AGCM addressed a first letter with recommendations to seven major influencers and eleven companies owning the brands embedded in SMIs' posts and a second letter to "smaller" influencers, inviting them to insert a clear indication of the commercial nature of their communications if the latter derived from a paid partnership or a free supply of products.61 In particular, the AGCM emphasised the importance of using the communication tools made available on the social media platform, such as specific hashtags to warn the consumer in a prominent way (e.g. \#pubblicità,62 \#sponsorizzato,63 \#advertising, \#inserzioneapagamento64 or, in cases of free supply of a product, \#prodottofornitoda65).

The response to the AGCM's interventions has been largely successful.66 SMIs

\footnotetext{
${ }^{58}$ AGCM, Relazione annuale sull'attività svolta, 237.

${ }^{59}$ Legislative Decree, 06/09/2005, n. 206, in Gazz. Uff. 8 October 2005, n. 235, S.O. Article 22 and Article 23 transpose, respectively, Article 7 and the "black list of unfair practices" listed in the Annex I of the UCPD.
}

\footnotetext{
${ }^{60}$ Moral suasion is an administrative tool that can be issued by the person responsible for administrative proceedings and addressed to traders in order to remove potentially unlawful aspects of commercial practice. It is essentially an instrument for preventing and reducing administrative proceedings. See, Guido Alpa and Antonio Catricalà, Diritto dei consumatori (Il Mulino 2016), 217-218.

${ }^{61}$ See, AGCM, Comunicato Stampa 24 July 2017; AGCM, Comunicato Stampa "Pubblicità trasparente su social media, influencer recepiscono le indicazioni AGCM ma il monitoraggio sul fenomeno proseguirà", 1 december 2017, http://www.agcm.it/media/comunicati-stampa/2017/12/alias-9049; AGCM, Comunicato Stampa "Seconda moral suasion per influencer: pubblicità occulta vietata sempre, anche sui social network", 6 august 2018, http://www.agcm.it/media/comunicatistampa/2018/8/alias-9449.

62 Translation: "advertising”.

63 Translation: "sponsored”.

64 Translation: "paid advertisement".

65 Translation: "product supplied by".

${ }^{66}$ AGCM, Comunicato Stampa 1 december 2017; AGCM, Comunicato Stampa "L'Antitrust chiude anche la seconda moral suasion su influencer e marchi, ma avvia istruttoria per possibili promozioni occulte, 11 december 2018, http://www.agcm.it/media/comunicati-stampa/2018/12/L'Antitrust-
} 
have used the authority's suggestions to highlight commercial links with brands or, in contrast, they have deleted "tags" that were generating an advertising effect. Furthermore, the AGCM's lesson was also implemented for posts that were not objects of the letters of moral suasion. Meanwhile, brands have demonstrated their efforts at ensuring transparency via contractual means, by requiring their testimonials to make the UGC's commercial intent evident according to the AGCM's recommendations.67

Despite the positive reaction of the operators to the moral suasion actions, upon notification from the Unione Nazionale Consumatori68 the AGCM started a preliminary investigation against two companies: Alitalia (Italy's flag carrier) and AEFFE s.p.a. (company related to fashion designer Alberta Ferretti) and thirteen big influencers.69 The new investigation, focused on a series of posts published by different SMIs who wore a Ferretti clothing line where the Alitalia logo was shown prominently. 70 The procedure ended with the decision no. $27787 / 2019$ and the adoption of formal commitments by the subjects involved.71 To meet the concerns of the Authority, both Alitalia, AEFFE and the influencers essentially proposed informational and contractual measures. For instance, Alitalia offered to: 1) send a formal communication to the branches of the company involved in the influencer marketing, recommending to ensure the highest level of consumer protection and the adoption of any appropriate measure to prevent hidden advertising; 2) adopt guidelines to ensure the principle of transparency in commercial communications (the respect of such guidelines will become a contractual obligation for influencers working with the company); 3) in all trademark license, insert a standard clause to oblige commercial partners to actively operate in order to prevent hidden advertising. 72 Similarly, AEFFE proposed to: 1) inform all the celebrities - who will receive or have already received gifts from the company - about the transparency obligations in commercial communication; 2) contractually oblige the testimonials to the respect of the transparency duties and monitor their compliance with such contractual obligations. Finally, the influencers committed themselves to make the commercial intent of the communication

chiude-anche-la-seconda-moral-suasion-su-influencer-e-marchi,-ma-avvia-istruttoria-per-possibilipromozioni-occulte.

${ }^{67}$ AGCM, Comunicato Stampa 11 december 2018.

${ }^{68}$ Unione Nazionale Consumatori is an Italian Consumer Association, https://www.consumatori.it. About the notification, see in particular, https://www.consumatori.it/comunicati-stampa/antitrustsegnalazione-alitalia-alberta-ferretti-influencer-marketing/

${ }^{69}$ Alberta Ferretti was also among the recipients of the first moral suasion of 2017.

${ }^{70}$ AGCM, Comunicato Stampa 11 december 2018.

71 AGCM, decision no. 27787 (proceeding PS11270), in Bollettino no. 23 of 10 June 2019, https://www.agcm.it/dotcmsdoc/bollettini/2019/23-19.pdf. The decision of the Authority has the effect to render the commitments offered by the trader legally binding.

72 In case of violation of the clause, the commercial partner coule be sanctioned or the contract terminated. 
more evident through the adoption of clear mentions on their posts (e.g. through hashtags such as "suppliedbyBRAND”, "BRANDgift”, "pubblicitàBRAND”, "advertisingBRAND”, "inserzioneapagamentoBRAND", etc.). In addition, one influencer proposed to periodically publish on her social media profile educational posts about the importance of respecting the rules on marketing transparency. Such commitments were positively evaluated by the AGCM, becoming then legally binding for the traders.

\subsubsection{The decision of the Advertising Self-Regulation Jury}

Influencer marketing has been also at the centre of a recent decision issued by the Giurì di Autodisciplina Pubblicitaria (= Advertising Self-Regulation Jury).73 It has to be preliminarily stated that the Giurì is an organ of the Istituto di Autodisciplina Pubblicitaria ("IAP") and its powers include enacting the Codice di Autodisciplina della Comunicazione Commerciale (hereinafter, "the Code"). 74 The latter is a code of conduct that is binding only for entities that have voluntarily adhered to it or have concluded a contract containing a clause on acceptance of the Code. 75 Therefore, it is an instrument of private regulation.

In the case brought before the Giurì a well-known Italian rapper published some pictures and Instagram stories on the occasion of a visit to the Peugeot stand during a sporting event. Framing the brand and the cars in his videos, the influencer said: "they are presenting me with all the new Peugeots that are coming out and now I'll show you all of them, one by one [...] you see, you come to the international tennis tournament, you shut yourself in the car on display and put the seat massager on and you're okay".76 Peugeot was then tagged at the beginning of the Instagram story.

When the case was referred to the Giurì the latter had to decide upon the alleged violation of the transparency rules on commercial communications (specifically Article 7

\footnotetext{
${ }^{73}$ Giurì autodisciplina pubblicitaria, decision no. 45 of 26 June 2018, in Rivista di Diritto Industriale 2018, 6, II, 376. For a comment, see Chiara Pappalardo, 'Influencer e Autodisciplina Pubblicitaria prime applicazioni della Digital Chart' (2018) 6 Rivista di diritto industriale 388.

${ }^{74}$ Codice di Autodisciplina della Comunicazione Commerciale (=Advertising Self-Regulation Code), available here https://www.iap.it/codice-e-altre-fonti/il-codice/ (Italian only).

${ }^{75}$ Maurizio Fusi and Paolina Testa, L'autodisciplina pubblicitaria in Italia: rassegna completa delle decisioni del Giurì con una introduzione all'ordinamento autodisciplinare (A. Giuffrè 1983); Nicolò Lipari, 'Il ruolo del giudice nella crisi delle fonti del diritto' (2009) Riv trim dir proc civ 479; Luigi Carlo Ubertazzi, 'Le PCS e il futuro dell'autodisciplina' (2010) 4 Diritto industriale 374; Vincenzo Di Cataldo, 'Pratiche commerciali scorrette e sistemi di enforcement' (2011) Giurisprudenza commentata 803; Adriano Vanzetti, 'Legislazione e diritto industriale' (2011) Rivista di diritto industriale 803.

${ }^{76}$ Translation from Italian.
} 
of the Code). 77 However, the procedure focused on the conduct of the main sponsor only. This was because the company managing the image of the rapper was not correctly sued.78 This procedural drawback nevertheless permitted deciding on the issue of the imputability of the message.

Interestingly, Peugeot was found both directly and indirectly liable for the conduct of the influencer. First, the Giurì ascertained that there was a "material connection"79 between the sponsor and the influencer, demonstrated by the sponsorship contract. The visit to the Peugeot stand was a contractual obligation of the SMI and the creation and sharing of the posts about that event were causally linked to that contractual relationship. Therefore, the SMI acted as an auxiliary agent of Peugeot (thus, integrating the indirect liability of the brand) 80 . Second, the sponsorship contract explicitly obliged the influencer to create four Instagram Stories in a specific car model during the sporting event and Peugeot staff actively participated in the shooting of the videos. Therefore, from the beginning the brand was able to "supervise" the behaviour of the influencer, control his compliance with the principle of transparency in commercial communications, and stop his illicit conduct in a timely manner. In addition, Peugeot was negligent in not providing specific contractual measures to prevent or sanction the eventual unlawful act of its testimonial (direct liability).

A second aspect of interest in the decision is the assessment of the "material connection" between the brand and the influencer. In the case at stake there were few doubts about the presence of this element, given the uncontested existence of a sponsorship

\footnotetext{
${ }^{77}$ Article 7 of the Code establishes that: "Commercial communication must always be recognizable as such. In the media and in the forms of commercial communication in which any content and information of other kinds are disseminated, commercial communication must be clearly distinguished by means of suitable measures".

${ }^{78}$ Nevertheless, with reference to the influencer, the Giuri noted that it was hard to believe that the rapper, operating in show business for more than ten years, was not aware of the provisions of the Code.

${ }^{79}$ It is interesting that the Italian Jury refers to the US concept of "material connection". The latter is provided at 16 CFR Part 255, which sets the guidelines on endorsement and testimonials to prevent deceptive practices. A material connection is defined as a condition that is likely to affect the weight or credibility of an endorsement, such as, for example, a business or family relationship, the provision of free products or other benefits. If not evident from the context the material connection has to be disclosed by the influencer (16 C.F.R. § 255.5 (2017)). Also, in the US the phenomenon of influencers has been captured by unfair commercial practice rules (Section 5, Federal Trade Commission Act (15 U.S.C. 45)). Cf. Boerman and others, 'Sponsored Blog Content: What Do the Regulations Say: And What Do Bloggers Say'; Laura E. Bladow, 'Worth the click: why greater FTC enforcement is needed to curtail deceptive practices in influencer marketing' (2018) William and Mary Law Review 1123; Lauren Myers, 'A picture is worth a thousand material-connection disclosures: Endorsers, Instagram, and the federal trade commission's endorsement guides' (2016) 66 Duke LJ 1371; Ava Farshidi, 'Evaluating the FTC Endorsement Guidelines through the Career of a Fashion Blogger' (2018) 9 Harv J Sports \& Ent L 185 .

${ }^{80}$ Peugeot was found liable as per Article 2049 of the Italian Civil Code, which contains a hypothesis of vicarious liability of the principals for the actions of their agents.
} 
contract between Peugeot and the SMI. However, the Giurì pointed out that, even in the absence of a contract, the advertising nature of a communication can be ascertained via presumptions. This does not mean taking account the subjective motivations of the parties (which are legally irrelevant) but considering the objective content of the communication in its context. 81

Therefore, according to the Giurì, the commercial nature of the influencer endorsement was

"not immediately recognisable to the average consumer and, a fortiori, to the more vulnerable consumer-follower. Indeed, the average consumer neither knows nor has to know about the existence of a material connection between the endorser and the advertiser [...]. On the contrary, it is highly likely that, if properly informed about the material connection between the endorser and the advertiser - and therefore, about the advertising nature of the endorsement (for example, through a disclaimer like "Advertising" placed at the beginning and at the end of the Story) - consumers would assign a different value and credibility to the endorsement. In this way, their freedom of economic self-determination will be guaranteed".82

Such reasoning is particularly interesting when the Giurì classifies the social media user as a more vulnerable category of consumers. These users are more exposed to hidden advertising due to the very structure of social media, which increases the risk of confusion between advertising, information and non-commercial communications compared to traditional mass media. 83

Finally, with reference to the form of disclosure of a material connection, neither the Giurì nor the Code establish specific rules about it. However, the Self-Regulation Jury expressly refers to the "Digital Chart",84 a document issued by the IAP in 2016 listing a series of recommendations for promoting the recognisability of commercial communication in online advertising. The Chart is indicated as the main reference point not only for helping operators to comply with Article 7 of the Code but also to ensure the legal certainty of self-regulation provisions and the predictability of the decisions of the

\footnotetext{
${ }^{81}$ In the case, the judge noted that: the videos showed prominently the logo of the car manufacturer and framed a specific car model, thus enhancing the visibility of the brand; no other brands were shown; the tag indirectly redirected to Peugeot's official page; the products of the brand were presented in a praising tone; and the visit of the influencer at the stand was also mentioned in Peugeot's social media narrative as an event of its own marketing campaign "\#DriveToTennis". So, even via presumptions, it could have been possible to affirm the material connection in the case.

${ }^{82}$ Giurì autodisciplina pubblicitaria, decision no. 45 of 26 June 2018, p. 10.3.

${ }^{83}$ Ibid.

84 IAP, Digital Chart, https://www.iap.it/wp-content/uploads/2017/11/Digital-Chart-IAPVERSIONE-ONLINE-ENG.pdf
} 
Giurì.85 At the time of the decision the Digital Chart was not binding but the Jury nevertheless recognised a para-legal force to it: following the rules embedded in the Chart created de facto a presumption (iuris tantum) of compliance with the Code. Resolving any potential doubt about its scope of application the IAP has recently incorporated the Chart into the Code. Since the 29th April 2019 the provisions of the Digital Chart are enforceable against all its adherent market operators.86

\subsection{The German experience}

German case law is particularly stimulating from a comparative perspective, since German courts have registered a quite surprisingly high number of cases against influencers over the last two years. In ascertaining compliance with the consumer protection framework the German decisions have focused on two main aspects: 1) when the influencer has a duty to disclose, and 2) the form of the disclosure.

\subsubsection{The disclosure duty}

German case law is unanimous in subjecting influencers to the application of the Gesetz gegen den unlauteren Wettbewerb (= "German Act against Unfair Competition", hereinafter "UWG"). The latter constitutes the German implementation of the UCPD.

In 2017 the Landgericht Hagen established a violation of the UWG in the case of a fashion blogger publishing on Instagram pictures of outfits which redirected followers toward the brand's page through “\#” and “@” signs without a clear indication of the commercial intent.87 Such a misleading practice by the SMI was found to be in contrast with § 5a abs. 6 UWG (which essentially implements Article 7(2) UCPD) because the influencer mixed commercial advertising and editorial content in a way that the consumer cannot immediately identify the commercial character of a post. Furthermore, the Court noticed a violation of $\$ 5$ a abs. 4 UWG, which obliges any trader to consider the information duties and other obligations set out in EU regulations or legal provisions for the implementation of EU directives for commercial communication, including advertising or marketing. By classifying the Instagram account of the influencer as an electronic communication the German judge applied the Telemedia Act ("Telemediengesetz",

\footnotetext{
${ }^{85}$ Giurì autodisciplina pubblicitaria, decision no. 45 of 26 June 2018, p. 10.4 .

${ }^{86}$ Regolamento Digital Chart sulla riconoscibilità della comunicazione commerciale diffusa attraverso internet, https://www.iap.it/codice-e-altre-fonti/regolamenti-autodisciplinari/digital-chart/

${ }^{87}$ LG Hagen, Urt. v. 13.09.2017, Az.: 23 ○ 30/17.
} 
hereinafter "TMG"), which implements the E-Commerce Directive. In particular, $§ 6$ abs. 2 TMG requires the service provider to disclose the identity of the sender and the commercial nature of the message.

According to the court, the SMI's practice was misleading because the influencer did not disclose the necessary information about the commercial nature of her actions (i.e. the posts were not accompanied by any hashtag like "\#ad" or "\#advertising"). Such a disclosure was considered necessary since the commercial intent of the SMI was not evident from the context. Interestingly, in line with the same argumentation of the Italian AGCM and Giurì, the German judge confirmed that that the misleading effect was exacerbated by the social media context: the branded posts were not published on a corporate webpage, where the average consumer can discern that the SMI is acting as a testimonial. On the contrary, they were inserted as regular posts, like and among those where the influencer was talking about outfits with her followers. Furthermore, the defendant was a popular figure not only among adults but especially among adolescents. Being vulnerable subjects, the court maintained that the duty to inform should have been more carefully implemented by the SMI. 88

In a similar case, the Kammergericht of Berlin clarified that the nature of advertisements must be disclosed whether the SMI receives a price for her performance or other kinds of benefits, such as discounts or free products.89 Such a conclusion appears the more justified as, despite any monetary payment, it is nevertheless possible to identify a consideration.

However, what if the SMI is acting independently and does not receive any direct benefit in exchange for her social media publication? Case law is divided on this matter and five decisions have been issued just in the past year.

In the first (chronologically) decision of this series the regional court of Berlin took a very restrictive approach:90 essentially, whenever a influencer tags a brand the publication must be marked as advertisement. Such an obligation also arises where an SMI buys the product pictured in a post, not receiving anything in return from the brand. The Court maintained that the presence of a hyperlink to brands was sufficient as a way to objectively advertise companies and, even if unintentionally, to affect the transactional decisions of followers. According to the German judge, if the purpose of the SMI in this case was, as declared, merely to keep her community updated about trends and news, a link to a brand

\footnotetext{
${ }^{88}$ Vulnerable subjects, due to mental factors, physical infirmity, age or credulity, are specifically taken into consideration in Section (3)(4) UWG.

${ }^{89}$ The case concerned the practice of a SMI publishing Instagram posts with "clean URLs" in exchange of price reductions. Clean URLs are "human-readable" links that represent the underlying resource (e.g. www.nameofthebrand.com/shop/shoes).

KG Berlin, Beschl. v. 11.10.2017, Az.: 5 W 221/17.

${ }^{90}$ LG Berlin, Urt. V. 24.05.2018, Az.: 52 O 101/18. The same principles have been followed in LG Karlsruhe, KfH, 21.03.2019, Az.: 13 O 38/18.
} 
was unnecessary. In determining the commercial nature of the SMI's practice the Court also took into consideration a quantitative aspect, i.e. the number of followers. Since this influencer could count on a large audience $(50,000$ followers), she was able to have an impact on the economic behaviour of several potential buyers. Such a situation of social media power could have helped her to leverage future business collaborations with companies and brands. Therefore, the SMI's Instagram activity was not motivated by personal reasons but was business-oriented. As such, she should have acted in compliance with §5a abs. 6 UWG and §6 abs. 2 TMG.

Partially reforming the first instance judgment, the Court of Appeal of Berlin recognised that the influencer was indeed a trader, who had made her self-branding into a business model. However, when a post contains editorial content, not remunerated in any way by a third party, in principle there is no commercial practice within the meaning of $\$ 2$ abs. 1 no. 1 UWG.91 For one of the three posts contested the Court admitted that it did not have to be labelled as advertisement because it was a (short) report on fashion trends and the influencer offered proof of having bought the clothing. Posts about fashion trends or editorial purposes, as such, do not indicate a support for the trader or the item. The link to the brand was justified by the will to prevent followers asking questions about the products. This argument was considered plausible by the German judge in analogy with what happens with fashion magazines, where information on manufacturers and sources of supply is usually published for the purpose of informing the readers about fashion trends.

Furthermore, the Court stressed the harmfulness implicit in the first instance decision, i.e. the obligation to label all the posts of an influencer as advertisements just because the SMI is a trader or her practice is able to generate any personal (future) gain. If everything is tagged as advertisement, then the purpose of protecting consumers from uniformed decisions risks being jeopardised and the disclosure will no longer serve the legislative intent. In other terms, the Court seemed to suggest that a duty to impose indiscriminate tags can generate a "lulling effect",92 where the disclosure will not even be noticed by consumers. To find external confirmation of its reasoning the Court stated that its conclusions were in line with the current guidelines of the German media authorities, "Advertising Identification of Social Media Offers"93, published in November 2018.

In a following case, involving the influencer Cathy Hummels, the Landgerichts München issued a preliminary injunction against the influencer, who had not

\footnotetext{
${ }^{91}$ Contra LG Karlsruhe, KfH, 21.03.2019, Az.: 13 O 38/18.

${ }^{92}$ On the lulling effect and the (un)expected drawbacks of a techno-legal solution, see W Kip Viscusi, The lulling effect: the impact of child-resistant packaging on aspirin and analgesic ingestions (AEA Papers and Proceedings 1984). vertising_identification_social_media_offers_2019.pdf
} 
tagged as an advertisement an Instagram post for which she did not receive any benefit or payment by the brand.94 As in the Berlin precedent the decision was not confirmed, but for different reasons. 95

The regional Court of Munich retained that, when there is no underlying consideration, an SMI's post cannot be considered as either advertising or commercial communication.96 Nevertheless, the judges affirmed that Hummels' posts were a commercial practice according to $\$ 2 \mathrm{Abs.} 1$ no. $1 \mathrm{UWG}$ : the posts were objectively able to favour undertakings and contribute to the self-promotion of the same influencer. However, the behaviour of the SMI was considered lawful because the commercial intent was evident from the context.

The arguments used by the court for justifying such a conclusion are not fully convincing. The Court makes a series of statements which denote a very high consideration of the knowledge and skills of the average social media user. The decision departs from the premise - highly criticised by data protection scholars - that users value their privacy and tend to protect it.97 Therefore, if an influencer chooses to have a public profile, accessible to anyone, it is because she does not want to use it only for personal purposes. Specifically, the SMI in question had 4,845,000 followers, so it was highly unlikely that all the people in her audience were her actual "friends". The fact that Hummels' Instagram account had the "blue check mark" - a sign attributed by the social media that certifies as authentic an account for a public figure, celebrity or global brand - was considered sufficient to show the influencer's intention to use her account for commercial purposes. Second, according to the court, consumers surfing on Instagram are generally conscious that public profiles are used for commercial purposes. This is even truer in the case of minors, who are digital natives and more aware than older generations about the professional nature of an

\footnotetext{
${ }^{94}$ LG München I, 10.04.2018 - 4 HKO 4985/18.

${ }^{95}$ LG München I, 29.04.2019 - 4 HK O 14312/18.

96 To this end, the court refers to the notion contained at $\$ 2$ abs. 2 no. 7 of the Rundfunkstaatsvertrag (the "Interstate Broadcasting agreement", hereinafter "RStV") according to which advertising means any form of announcement transmitted "in return for payment". Therefore, the information duties established at $\$ 7$ abs. $3 \mathrm{RStV}$ did not find application in the controversy at stake. Similarly, $\$ 2$ no. 5 b) TMG excludes from the definition of commercial communication those acts "compiled in an independent [manner] and in particular without financial consideration”.

97 Such an assumption clashes with the well-documented problem of the "privacy paradox": people express that they are very concerned about privacy but they do not act accordingly. See, Alessandro Acquisti and Jens Grossklags, 'Privacy and rationality in individual decision making' (2005) 3 IEEE security \& privacy 26; Patricia A Norberg, Daniel R Horne and David A Horne, 'The privacy paradox: Personal information disclosure intentions versus behaviors' (2007) 41 Journal of consumer affairs 100; Alessandro Acquisti, Laura Brandimarte and George Loewenstein, 'Privacy and human behavior in the age of information' (2015) 347 Science 509; Spyros Kokolakis, 'Privacy attitudes and privacy behaviour: A review of current research on the privacy paradox phenomenon' (2017) 64 Computers \& security 122.
} 
influencer.98 In other terms, such a decision seems to draw an equivalence between the notions of celebrity and trader.

\subsubsection{The form of the disclosure}

In a few cases German courts have also had the chance to clarify some important principles concerning the modalities of the disclosure of a post's commercial intent.

In a controversy about a commercial advertisement placed by a 20-year-old influencer, sponsoring a discount offered by a famous drugstore chain, the Celle Higher Regional Court maintained that the disclosure put in place was insufficient.99 Specifically, the influencer's post consisted of a picture accompanied by a textual post and followed by a list of six hashtags (among which was "\#ad”).100

Reversing the first instance ruling,101 where the Hannover District Court maintained that the SMI's advertising intent was evident at the first sight both from the context (i.e. a link to a store's page, the use of professional pictures and commercial language, such as "sparfüchse"102) and the unambiguous disclosure provided with the "\#ad", the appeal judges followed a different line of reasoning.103

Proceeding with assumptions, the Celle Court questioned whether one hashtag in a series might be noticed by the average consumer: the latter would probably read only the content of the post and not the list of tags placed at the end.104 Those hashtags can be taken into consideration by the consumer at a further (and optional) stage: if the reader

\footnotetext{
${ }^{98}$ In any case, according to the Court, Hummels' posts were not able to mislead minors, since the UCG was about yoga and how to travel with children, thus targeting a public of adult women.

${ }^{99}$ OLG Celle, Urt. v. 08.06.2017, Az.: 13 U 53/17.

100 The complete text of the post was: “...Guten Abend! An alle Sparfüchse: AUFGEPASST! NUR morgen gibt es in allen Filialen von ... \& im Online Shop 40\% Rabatt auf Augen Make-Up! Viel Spaß beim Einkaufen! ... Eyes: RdeL Young Super Star Mascara \& Maybelline New York The Rock Nudes Lidschatten Palette \#blackfriyay \#ad \#eyes \#shopping \#rabatt \#40prozent".

"Blackfriyay" (instead of the notorious "Black Friday", the beginning of the discount sales period before Christmas) is not a typo mistake by the author of the present article but was the exact hashtag displayed on Instagram by the influencer. Actually, the misspelling was used as an argument by the plaintiff to support the misleading nature of the post: the typo error was deliberate in order to give the false impression that the message was written by a person acting for private reasons. See, LG Hannover, 08.03.2017 - AZ: 23 O 5/17, § 6. The argument was dismissed by the judge, who recognised that rather than a misspelling, "blackfriyay" was a piece of slang popular among youths. Ibid., § 31 .

${ }^{101}$ LG Hannover, 08.03.2017 - AZ: 23 O 5/17.

${ }^{102}$ Translation: "bargain hunters" or "smart shoppers".

${ }^{103}$ The ratio decidendi was followed in KG Berlin, Beschl. v. 11.10.2017, Az.: 5 W 221/17.

${ }^{104}$ Ibid., § 12 .
} 
wants to explore the links and read other contributions related to that topic. 105 Neither could the fact that the hashtags were highlighted in a different colour have served the purpose of attracting followers' attention to the case: the font emphasis was nullified by the number of "\#", making it difficult to single out the information about the commercial nature of the post.106

Furthermore, the appeal judges completely defeated the evaluation of the first instance court with reference to the recognisability of the promotional intent from the context. This was first because the quality of the picture - which seemed to be professional - was not a decisive element.107 Second, the use of emoticons, typical of informal and friendly communications, is likely to be misleading about the real nature of the post.108 Third, if followers want to obtain complete and meaningful information about the commercial nature of a post they have to read all the lines of hashtags. Therefore, if they have to spend time looking at the entire disclosure, the promotional intent is videlicet - not recognisable "at first sight".109

Even more clearly, the Landgericht Heilbronn has questioned the validity of the mere use of "\#ad" to communicate the commercial intent of an Instagram post.110 According to the judge, such a disclosure is not immediately recognisable to the average follower.

\subsection{Comparative observations}

The Italian and German cases highlight the potential frictions between the activity of SMIs and the relevant legal framework. Significantly, they confirm the applicability of unfair commercial rules to the influencer marketing phenomenon. Also, for a different area of competences, German courts tend to qualify SMI profiles as information society services, thus requiring influencers to comply with the duty to make advertisements clearly recognisable.

Similarly, they consider it irrelevant whether an SMI has been actually paid or received any other kind of benefit such as free products or further forms of compensation. What has to be verified in order to attract disclosure obligations is the presence of a

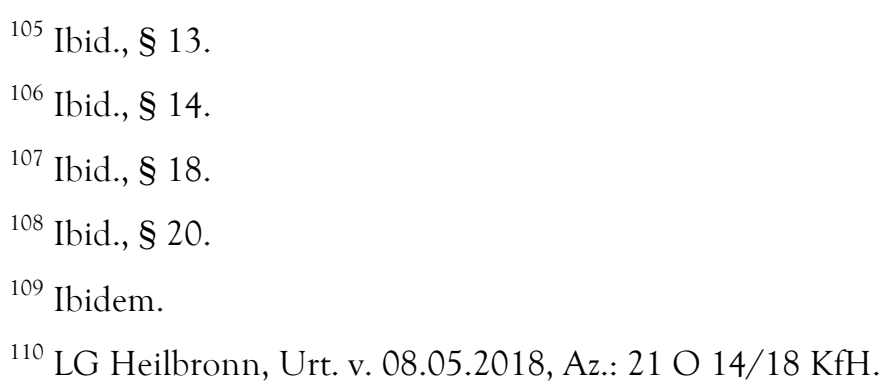


synallagmatic exchange, where performances do not have to necessarily result in monetary payment.

However, their responses do not always point in the same direction. On the one hand, the Italian decisions seems to take a more paternalistic approach. Both the AGCM interventions and the Advertising Self-Regulation Jury underline the situation of consumer weakness before the influencer practice: the very same social media structure, which gives the illusion of interaction among peers exposes the consumer to greater risk. If a SMI does not provide any disclosure it is going to be very hard for users to recognise the commercial intent of the trader and evaluate cum grano salis the communication to which they are exposed online. On the basis of such consideration the Jury takes an even more protective stance and maintains that the online user is a more vulnerable type of consumer. This classification must not be interpreted literally as referring to the normative category of vulnerable consumers (Article 5(3) UCPD). In that case the norm takes into consideration groups of individuals who, due to subjective circumstances like mental or physical infirmity, age or incredulity, deserve more protection. On the contrary, the Jury refers to external and objective factors, which are therefore unlikely to fall under the umbrella of Article 5(3) UCPD. Nevertheless, the Jury's argument seems to be used to construct a lower threshold for the notion of the average consumer, more in line with behavioural studies showing the difficulties that users face in identifying the commercial nature of posts on social media.111

On the German side the situation is more complex since case law appears to be divided on this point. While the first decisions seem to recognise a situation of impairment facing the average consumer in influencer marketing, the Landgerichts München depicts the social media user as a consumer who is particularly careful, if not even biased, regarding influencers. Especially where the latter have a high number of followers, the Court maintains that it can be reasonably presumed that they act with a commercial intent. A fortiori, younger generations are even more skilled, since they are more aware of social media mechanisms, purposes and uses. Therefore, in many circumstances no disclosure of the commercial intent is needed. Despite the same Court has stressed that the evaluation about the recognisability of the commercial intent is a case-by-case exercise and that the conclusions in the Hummels' case do not universally apply to all bloggers and influencers conducts, the principle therein followed are not entirely convincing. First, because the image of the consumer emerging from such a decision appears to be extremely idealistic. Second, the reasoning of the Court appears to be based on a disputable hidden premise: all acts of traders are advertisements. However, just because influencers are (new forms of) celebrities this does not automatically entail that all their actions are always moved by a commercial intent. Similarly, even when they qualify themselves as traders, through some mechanisms made available on a social network (like the "blue check mark"), it cannot be presumed that all their posts are an outcome performed in the context of their business or

${ }^{111}$ Consortium, Behavioural Study on Advertising and Marketing Practices in Online Social Media. 
profession. Imagine a professional publisher who wants to sell a personal book from his home library or a journalist who is occasionally contracted to sponsor a product (e.g. an Internet service provider). Should consumers conclude that all the social media posts of such subjects are commercial advertisements?

Another point of potential divergence among the two considered legal systems is the qualification of commercial intent when influencers promote a product without receiving any benefit from the brand. The German decisions bring such a hypothesis under the umbrella of commercial practice. This can be justified in light of the broad definition adopted in the German system at Article 2(1) UWG, which specifies that a commercial practice is "any conduct by a person for her own benefit or a third-party business [...] which conduct is objectively connected with promoting the sale of the procurement of goods or services". Such a definition is broader than the corresponding Article 2(b) UCPD in two ways: it introduces the personal gain coming from the performance of the practice as a constituent element of the definition, and it states that the conduct has to be "objectively connected" rather than "directly connected" to the promotion of goods or services. German courts have emphasised in particular the first part - the person's own benefit - to justify their conclusions with reference to the activity of SMIs acting independently.

On the Italian side the recent AGCM's decision no. 27787 has indirectly tackled the issue.112 In that case, the behaviour of one influencer was considered not covered by the scope of the Italian Consumer Code, because the SMI was able to prove she independently purchased the items at stores. Therefore, according to the AGCM, the SMI acted in her private capacity, not being involved in any contractual relationship with the brand.

This solution is in line with the general framework of advertisement regulation, where the national doctrine tends to emphasise the promotional intent of advertising rather than its effects.113 When an influencer independently reviews or talks about a product there is indeed a potential beneficial effect for the third-party brand, but the teleological approach should lead us to conclude that there is no advertisement where an SMI aims at objectively presenting products.114 Similarly, if a trader's conduct is not functional to the commercialisation of a product the act will be unlikely to fall under the notion of commercial practice under Italian law. 115

Finally, as for disclosure, in both legal systems courts and authorities have introduced some recommendations to make commercial intent clearly recognisable. The object of the provisions in all the cases examined was limiting Instagram influencers, therefore their

\footnotetext{
${ }^{112}$ AGCM, decision no. 27787/2019, § 37 and 52 .

${ }^{113}$ Ernesto Apa, La pubblicità commerciale. Struttura, natura e referenti costituzionali (Jovene 2011), 28-30.

${ }^{114}$ Pablo Fernandez Carballo-Calero, Pubblicità occulta e product placement (CEDAM 2004), 5.

115 Elena Bargelli, 'La nuova disciplina delle pratiche commerciali scorrette tra professionisti e consumatori:l'ambito di applicazione (art. 18 lett. A-D e art. 19 comma 1 cod. cons.)' in E Bargelli and others (eds), Pratiche commerciali scorrette e codice del consumo (Giappichelli 2008), 96.
} 
interventions essentially focused on how to use hashtags in a meaningful way for the consumer.

Interestingly, they both refer to national guidelines and codes of conduct as benchmarks for operators in the influencer marketing sector. The Italian Digital Chart, regulating the recognisability of commercial communication online, establishes some general principles. Influencers, for example, have to insert in the "initial part of the post or the communication" one label and/or tag from among "Pubblicità/Advertising", "Promosso da ... brand/Promoted by ... brand", "Sponsorizzato da ... brand/Sponsored by ... brand", "in collaborazione con ...". Similar rules are settled for disclosure through hashtags: here "\#ad" or one of its variants has to be included among the three first hashtags of a post. Meanwhile, if an influencer has received a product for free another label should be used: "prodotto inviato da ... brand".116

German media authorities have recently issued the guidance "Advertising Identification of Social Media Offers".117 On the basis of German law on unfair commercial practices and case law the media authorities propose an "identification matrix" to help influencers understand when disclosure is necessary and how it has to be done. The matrix distinguishes between disclosure duties depending on the type of content posted (text, image or video). Despite some slight differences due to the form of the UGC there are two common elements. First, the disclosure has to be provided at the beginning of the post or video (or as a permanent fade-in on the video); second, the identification of the commercial intent must be clearly legible and expressed with the label or the hashtag "werbung" or "anzeige" (= advertising). The German guidance seems to raise the standard of protection; not regarding the use of "\#ad" to be sufficient but requiring disclosure in the consumer's language. 118

Soft law and self-regulation mechanisms have grown exponentially in this area. Both at international and national level guidelines and recommendations have tried to regulate the influencer marketing phenomenon by offering some inputs to identify when there is a duty to disclose and how this should be expressed.119 However, such guidance takes into consideration mainly influencers and brands, and does not devote the same attention to the other relevant actor in influencer marketing: the platform.120

\footnotetext{
${ }^{116}$ Apparently in this case disclosure in English is not contemplated.

medienanstalten.de/fileadmin/user_upload/Rechtsgrundlagen/Richtlinien_Leitfaeden/Guideline_ad vertising_identification_social_media_offers_2019.pdf

${ }^{118}$ As required, for example, by BGH, 06.02.2014 - I ZR 2/11.

${ }^{119}$ For an overview of the soft law instruments, see Riefa and Clausen, 'Towards Fairness in Digital Influencers' Marketing Practices'.

${ }^{120}$ The UK Competition and Market Authority has announced the start of several investigations to clarify the role of platforms in influencer marketing (https://www.ft.com/content/0060cee0-1eeb-11e9b2f7-97e4dbd3580d). At the moment, indirect mention of platforms can be found in the FTC's FAQ
} 


\section{The return of the platform: design duties of social media}

Social media platforms play a key function in conveying an SMI's commercial communications. In order to identify their obligations in terms of transparency a preliminary taxonomical introduction is needed.

The social media usually employed by influencers is in the form of online social networks121 (e.g. Facebook, Twitter) and video sharing platforms122 (e.g., YouTube, Dailymotion), which have both been classified by the European Commission as "online platforms".123 Each category emphasises a different aspect of the platform: interaction among users and the possibility of making such social relationships visible characterise social networks, 124 while the possibility of generating and uploading audiovisual content is typical of video-sharing platforms. However, as can be easily understood, the boundaries between these two categories are blurring: on the one hand, video-sharing platforms allow

page (https://www.ftc.gov/tips-advice/business-center/guidance/ftcs-endorsement-guides-what-peopleare-asking). To comply with their disclosure obligations under the FTC Act, influencers can use the communication tools made available by social media. However, the authority strongly recommends evaluating such systems with a grain of salt. In particular, just because there is a built-in feature that allows for disclosing endorsement, this does not mean that the SMI disclosure's duties are automatically satisfied. For instance, it will necessary to consider whether the placement of the notice is able to attract users' attention, if the font is readable and if the language is unambiguous: "the ultimate responsibility for clearly disclosing a material connection rests with the influencer and the brand - not the platform" (https://www.ftc.gov/tips-advice/business-center/guidance/ftcs-endorsement-guides-what-people-areasking).

${ }^{121}$ Social networks have been described by the Commission as "services which enable users to connect, share, communicate and express themselves online or through a mobile app" (EC Commission, Case No COMP/M.7217 - FACEBOOK/ WHATSAPP, 2014, \$46, http://ec.europa.eu/competition/mergers/cases/decisions/m7217_20141003_20310_3962132_EN. pdf). According to Boyd and Ellison, social networks are "web-based services that allow individuals to (1) construct a public or semi-public profile within a bounded system, (2) articulate a list of other users with whom they share a connection, and (3) view and traverse their list of connections and those made by others within the system". Danah M Boyd and Nicole B Ellison, 'Social network sites: Definition, history, and scholarship' (2007) 13 Journal of computer-mediated Communication 210. See also, Eleonora Rosati and Giovanni Sartor, 'Social networks e responsabilità del provider' (2012) Riordan, The liability of internet intermediaries, 41.

${ }^{122}$ Riordan, The liability of internet intermediaries, 42.

${ }^{123}$ An online platform has been preliminarily defined as: "an undertaking operating in two or (multi)sided markets, which uses the Internet to enable interactions between two or more distinct but interdependent group of users so as to generate value for at least one of those groups. Certain platforms also qualify as Intermediary Service Providers" (EC Commission, Public consultation on the Regulatory Environment for Platforms, Online Intermediaries, Data and Cloud Computing and the Collaborative Economy, 5, http://ec.europa.eu/newsroom/dae/document.cfm?doc_id=10932).

${ }^{124}$ Boyd and Ellison, 'Social network sites: Definition, history, and scholarship'. 
a certain degree of interaction and networking effects between vloggers and audiences and, on the other hand, social networks' UGC can consist of videos. Therefore, in general terms, social media platforms - comprising social network sites and video-sharing platforms - can be described as Web 2.0 Internet intermediaries connecting two or more groups of users and allowing the latter to 1) create a public or private profile on the platform, and 2) generate and share UCG with a list of selected users or the general public.

\subsection{Video-sharing platforms and the Audiovisual Media Service Regime}

Coming now to the applicable legal framework, a preliminary reference that comes into play is media law and, in particular, the Audiovisual Media Service Directive ("AVMSD"). 125 The latter, which aims at coordinating the regulation of audiovisual media at EU level, has been recently revised to cope with technological developments in the online fruition of content.126 Notably, the review of the AVMSD involved the expansion of its scope of application, which now expressly includes platforms such as YouTube (captured by the notion of "video-sharing platforms service") 127.

Importantly, the amended AVMSD requires Member States to ensure that platforms implement appropriate measures to make audiovisual commercial communications easily recognisable, not only where a platform markets, sells or arranges communications (e.g. native advertising), but also where the provider does not have any form of control over them (which would be usually the case with influencer marketing).128

${ }^{125}$ Directive 2010/13/EU on the coordination of certain provisions laid down by law, regulation or administrative action in Member States concerning the provision of audiovisual media services [2010] OJ L 95/1; as amended by Directive (EU) 2018/1808 on the coordination of certain provisions laid down by law, regulation or administrative action in Member States concerning the provision of audiovisual media services in view of changing market realities [2018] OJ L303/69. See also the contribution of Madeleine de Cock Buning, in this Volume.

${ }^{126}$ As stressed by Valcke and Ausloof, despite the technologically neutral approach of the AVSMD national legislators have struggled to fit online services into the general framework provided for audiovisual services. Peggy Valcke and Jef Ausloos, 'Audiovisual Media Services 3.0:(Re) Defining the scope of European broadcasting law in a converging and connected media environment', The Palgrave Handbook of European Media Policy (Springer 2014).

${ }^{127}$ This addition is able to capture the influencer marketing phenomenon, imposing some specific duties on the online intermediary, which does not usually have any editorial control over influencers' UGC. See definition at Article 1(1)(b), Directive (EU) 2018/1808. The Directive has also extended the obligation to protect minors on video-sharing platforms, detailing several new provisions. However, such an analysis goes beyond the scope of the present contribution.

128 Article 28b(2) Directive (EU) 2018/1808. Regarding the notion of audiovisual commercial communications, the latter is particularly broad. The AVMSD defines such communications as: "images with or without sound which are designed to promote, directly or indirectly, the goods, services or image of a natural or legal person pursuing an economic activity; such images accompany, or are included in, 
The Directive does not establish any specific minimum requirement for expressing the disclosure of the commercial intent but it does provide a set of guidelines and a nonexhaustive list of appropriate measures that can be implemented by a video-sharing platform.129 Among said measures the AVMSD mentions a few examples that can be seen as particularly relevant in the case of influencer marketing: for instance, the possibility to apply in the terms and condition of the video-sharing platform services the requirements for ensuring the transparency of the commercial communication not arranged by the platform; the provision of a functionality for users who upload user-generated videos to declare whether such videos contain audiovisual commercial communications as far as they know or can be reasonably expected to know, or the provision of educational measures to raise users' awareness and media literacy about the transparency enhancing tool of the platform. 130

The AVMSD allows a certain degree of discretion in choosing the most appropriate means of disclosing the commercial intent of a communication. An evaluation will have to be conducted considering the concrete circumstances of the video-sharing131, and the practicability and proportionality of the measures.132 In any case, the Directive specifies that said measures cannot constitute a way to introduce a general duty to monitor the

a programme or user-generated video in return for payment or for similar consideration or for selfpromotional purposes. Forms of audiovisual commercial communication include, inter alia, television advertising, sponsorship, teleshopping and product placement". Article 1(1)(f) Directive (EU) 2018/1808.

${ }^{129}$ It also encourages self-regulation initiatives through Union codes of conduct (Article 4a Directive (EU) 2018/1808.

${ }^{130}$ The list of measures detailed at Article 28(b)(3) are likely to be applied in combination. Otherwise, if we take for example case sub b) (to include and apply "in the terms and conditions of the video-sharing platform services the requirements set out in Article 9(1) for audiovisual commercial communications that are not marketed, sold or arranged by the video-sharing platform providers") it is reasonable to foresee that the latter alone is going to be largely ineffective in practice. It is well documented in the literature that the majority of consumers do not usually read the terms of services of online platforms. See, bibliography supra note 17 and Special Eurobarometer 447 on online platforms (2016), http://ec.europa.eu/information_society/newsroom/image/document/2016-

24/ebs_447_en_16136.pdf

${ }^{131}$ Such as the nature of the content, the harm it may cause and the characteristics of the category of persons to be protected, as well as the rights and legitimate interests at stake.

${ }^{132}$ Article 28b(3)(1 ${ }^{\circ}$ subparagraph) Directive (EU) 2018/1808. 
activity performed on a platform.133 As evident, it is quite a general clause that is likely to be determined by the competent national authorities or regulatory bodies.134

The AVMSD can constitute an important reference point for constructing the transparency duties of platforms. However, a few clarifications are needed. Within the definition of video-sharing platform services fall not only "pure" video-sharing platforms, such as YouTube, Dailymotion or TikTok, but also services like Facebook and Instagram, as long as video sharing is one of their essential functionalities. The assessment of such a criterion is not always going to be an easy task. Is the functionality of the "Stories"135, where images and short videos are presented, an essential feature of Instagram and Facebook? Or is it merely ancillary? The same Directive recognises the difficulties embedded in this kind of evaluation by affirming that:

"in order to ensure clarity, effectiveness and consistency of implementation, the Commission should, where necessary, issue guidelines, after consulting the Contact Committee, on the practical application of the essential functionality criterion of the definition of a 'video-sharing platform service'. Those guidelines should be drafted with due regard for the general public interest objectives to be achieved by the measures to be taken by video-sharing platform providers and the right to freedom of expression”.136

Furthermore, the rules on disclosure apply as long as audiovisual commercial communication is embedded in a video or image that is incorporated into or accompanies a video. Therefore, not all social media influencers' activities will be captured by the AVMSD: notably a large part of advertising practices, expressed in the form of text, pictures or GIFs137, will escape from the framework of the Directive. If this can be explained in

\footnotetext{
${ }^{133}$ Article 28b(3)(2 ${ }^{\circ}$ subparagraph) Directive (EU) 2018/1808 affirms that : "those measures shall not lead to any ex-ante control measures or upload-filtering of content which do not comply with Article 15 of Directive 2000/31/EC". It is reasonably to wonder what kind of efficient ex-ante control measures or upload-filtering system do not essentially imply a general obligation to monitor the information shared via the platform. On filters and their compatibility with Article 15 of the e-commerce Directive, see Case C-70/10 Scarlet Extended SA v Société belge des auteurs, compositeurs et éditeurs SCRL (SABAM) [2011] ECLI:EU:C:2011:771 and C-360/10, Belgische Vereniging van Auteurs, Componisten en Uitgevers CVBA (SABAM) $v$ Netlog NV [2012] ECLI:EU:C:2012:85. For similar concerns in the context of recently approved Directive on Copyright in the Digital Single Market, see Martin Kretschmer and others, 'The Copyright Directive: Articles 11 and 13 must go. Statement from European Academics in advance of the Plenary Vote on 26 March 2019', https://www.create.ac.uk/blog/2019/03/24/the-copyrightdirective-articles-11-and-13-must-go-statement-from-european-academics-in-advance-of-the-plenary-voteon-26-march-2019/.

${ }^{134}$ See, in particular, Article 28b(5) Directive (EU) 2018/1808.

${ }^{135}$ Instagram or Facebook "Stories" are a feature made available by the said social media that allows users to publish images or short videos that remain online for 24 hours.

${ }^{136}$ Recital 5 Directive (EU) 2018/1808.

${ }^{137}$ Recital 6 Directive (EU) 2018/1808 explicitly excludes animated images from the scope of the AVMSD.
} 
light of the television-like scope of application of the AVMSD, the practical effect could be a fragmentation of the disclosure mechanisms that platforms have to put in place. Taking into consideration hybrid services like Facebook or Instagram, where is possible to post content in the form of both videos and images, the appropriate measure for ensuring the recognisability of commercial communication would have to be implemented only with reference to videos. Platforms will not be obliged to ensure the same disclosure measures for advertisements contained in pictures or text messages.

This may constitute a major flaw in the implementation of the principle of transparency in the context of influencer marketing. However, this apparent gap could be filled in coordination with the provisions of the UCPD.138

\subsection{Social media platforms and consumer protection: perspectives on the application of the UCPD and the New Deal for Consumers}

As already discussed in Section III, the UCPD applies to business-to-consumer relationships and online platforms usually fall under the notion of traders.139 This implies that social media has to comply with the transparency duties arising from the standard of diligence required by Article 5(2) UCPD.140 As stressed by the European Commission in its guidance on the implementation/application of the UCPD, platforms cannot mislead their users/consumers by either action or omission.141 This can be exemplified in the duty

\footnotetext{
${ }^{138}$ See also Recital 46 Directive (UE) 2018/1808.

139 The classification of a platform as a trader has to be performed on a case-by-case analysis. However, considering the broad notion of a trader adopted in the UCPD, online platforms are likely to be subject to unfair commercial practices rules. Cf. Riefa and Clausen, 'Towards Fairness in Digital Influencers' Marketing Practices', p. 67; Pierre Hausemer and others, Exploratory study of consumer issues in online peerto-peer platform markets, 2017), 104; Emma Psaila and others, Exploratory study of consumer issues in online peer-to-peer platform markets. Task 5 Report - Legal Analysis Report, 2017, 57 ff.; Valentina Moscon and Reto M Hilty, 'Online Intermediaries as a Vehicle for Acts of Unfair Commercial Practices and Trade Secrets Infringement: What Liability within the European Legal Framework?' in Giancarlo F. Frosio (ed), The Oxford Handbook of Intermediary Liability Online (Oxford University Press forthcoming).

140 Commission Staff Working document "Guidance on the implementation/application of Directive 2005/29/EC on Unfair Commercial Practices" accompanyning the document "Communication from the Commission to the European Parliament, the Council, the European Economic and Social Committee and the Committee of the Regions, A comprehensive approach to stimulating cross-border e-Commerce for Europe's citizens and businesses"; Psaila and others, Exploratory study of consumer issues in online peer-to-peer platform markets. Task 5 Report - Legal Analysis Report, 60-61.

141 Commission Staff Working document "Guidance on the implementation/application of Directive 2005/29/EC on Unfair Commercial Practices" accompanyning the document "Communication from the Commission to the European Parliament, the Council, the European Economic and Social Committee and the Committee of the Regions, A comprehensive approach to stimulating cross-border e-Commerce for Europe's citizens and businesses", 114.
} 
to provide "appropriate measures which - without amounting to a general obligation to monitor or carry out fact-finding (see Article 15(1) e-Commerce Directive) - enable relevant third party traders to comply with EU consumer and marketing law requirements and users to clearly understand with whom they are possibly concluding contracts".142 Among the appropriate measures, the Commission suggests designing web-structures in a way that can support third-party traders in presenting the information that they are statutorily obliged to give to platform users.143 In other words, similarly to what was established in the AVMSD, the Guidance of the Commission imposes a duty to design the interfaces and architectures of platforms in order to facilitate the provision of relevant information to users. The duty to disclose will remain with influencers and brands but the platform has to create a system which will allow the commercial intent of a post to be expressed in a recognisable and meaningful way. Failure to comply with this design obligation would result in violation of the duty of diligence enshrined in the UCPD.

Embedding transparency requirements into the design of an interface is an interpretation in line with the intention of the European legislator of the UCPD for two reasons. First, cuius commoda, eius et incommoda. The value of platforms does not merely lie in intermediation. The majority of social media business models imply the monetisation of users' interactions to the commercial advantage of the same platform.144 Through (dubious) intellectual property clauses in their terms and conditions 145 platforms reserve the right to exploit UGCs and data not only to enhance the online user experience (thus ameliorating their own services and rendering them more attractive) but also to pursue further purposes (e.g. online behavioural advertising).146 In light of the contractual relationship between a platform and its users it is reasonable to assume that the former has a positive duty to cooperate in shaping the online experience in a fair way for all the actors involved. Such a duty of cooperation is indirectly supported by other considerations. Given the transnational nature of the influencer phenomenon an SMI will be able to comply with several national rules only thanks to the technological support of a platform. Think, for

\footnotetext{
${ }^{142}$ Ibid.

${ }^{143}$ Ibid., 114-115. As similarly affirmed in the Communication from the Commission to the European Parliament, the Council, the European Economic and Social Committee and the Committee of the Regions "A European agenda for the collaborative economy", 10.

${ }^{144}$ Olivier Sylvain, 'Intermediary Design Duties' (2018) 50 Conn L Rev 203; Inge Graef, EU Competition Law, Data Protection and Online Platforms: Data as Essential Facility: Data as Essential Facility (Kluwer Law International BV 2016).

${ }^{145}$ Several concerns have been raised about the unfairness of such clauses. Cf. Brendan Van Alsenoy and others, From social media service to advertising network. A critical analysis of Facebook's Revised Policies and Terms, 2015).

${ }^{146}$ On the use of data by online platforms for online behavioural advertising, cf. FZ Borgesius, 'Behavioral Targeting: How to Regulate?(Diss.)' (2014) Institute for Information Law (IViR), University of Amsterdam; Sophie C Boerman, Sanne Kruikemeier and Frederik J Zuiderveen Borgesius, 'Online behavioral advertising: A literature review and research agenda' (2017) 46 Journal of Advertising 363.
} 
example, about the duty to provide information in the language of the consumer: the mere label "\#advertising" could be unclear or difficult to understand for a German consumer.147 Such issues can be overcome only if the platform makes the tag "portable", for example, thanks to an automated translation tool.

Second, platforms have become a powerful gatekeeper. Being the point of access for influencers they are in the best position to realise the legislative intent in a timely and effective manner. Introducing friction in the influencer's journey onto the platform, namely a mandatory choice that the SMI has to make when she is to upload content onto the platform, represents a light-touch and efficient form of co-regulatory measure.148 As a corollary, one has also to consider that platforms have an interest in ensuring the quality and trustworthiness of their services. Furthermore, if they offer a built-in system that can facilitate the compliance of influencers with the relevant legal framework SMIs will be more willing to choose platforms offering such features than those who do not. Not surprisingly, many social media platforms have already voluntarily introduced some options that allow influencers to comply with advertising disclosure duties.149

In spite of the Commission guidance the above-mentioned platforms' design duty is still controversial. The guidelines on the UCPD can indeed provide some relevant recommendations but, as Slewo150 recently recalled, such documents remain a soft law instrument. The main doubt about the applicability of the hermeneutic interpretation provided in the guidance to the UCPD comes from the proposal for a directive on better enforcement and modernisation of $\mathrm{EU}$ consumer protection rules (the "Omnibus Directive").151 This legislative proposal translates into the black letter of the law many of

${ }^{147}$ This German consumer example is inspired by BGH, 06.02.2014 - I ZR 2/11.

${ }^{148}$ Cf. Busch, 'Self-Regulation and Regulatory Intermediation in the Platform Economy'. On frictions, as inefficient way to reach desirable social goals, see Paul Ohm and Jonathan Frankle, 'Desirable Inefficiency' (2018) 70 Fla L Rev 777.

${ }^{149}$ Like the already mentioned Facebook "Branded Content Tool" (see Section 2) or the similar one made available by Instagram (https://business.instagram.com/a/brandedcontentexpansion).

${ }^{150}$ In this case, involving the right to withdraw for a mattress whose protective seal has been removed by the consumer after delivery, the ECJ disregarded the interpretation offered in DG Justice Guidance document concerning Directive 2011/83/EU of the European Parliament and of the Council of 25 October 2011 on consumer rights, amending Council Directive 93/13/EEC and Directive 1999/44/EC of the European Parliament and of the Council and repealing Council Directive 85/577/EEC and Directive 97/7/EC of the European Parliament and of the Council (see, in particular, p. 55). Case C-681/17 Slewo - schlafen leben wohnen GmbH v Sascha Ledowski [2019] ECLI:EU:C:2019:255.

${ }^{151}$ Proposal for a Directive of the European Parliament and of the Council amending Council Directive 93/13/EEC of 5 April 1993, Directive 98/6/EC of the European Parliament and of the Council, Directive 2005/29/EC of the European Parliament and of the Council and Directive 2011/83/EU of the European Parliament and of the Council as regards better enforcement and modernisation of EU consumer protection rules, COM/2018/0185 final - 2018/090 (COD). The latter is at the moment in the final stages of the legislative procedure as a part of the "New Deal for Consumers" (Communication from the Commission to the European Parliament, the Council and the European Economic and Social 
the suggestions already proposed in the guidance to the implementation/application of the UCPD but unexpectedly leaves aside the design duty concerning the interface. 152

It is true that the Omnibus Directive introduces an obligation for platforms to declare "whether the third party offering the goods, services or digital content is a trader or not, on the basis of the declaration of that third party to the online marketplace". 153 This presupposes that platforms now have to put in place mechanisms and web structures for users to declare their legal status. 154 However, this addition might not be sufficient to address the problem here at stake.155 The influencer will have indeed the possibility of disclosing whether she is a trader but it is uncertain whether she will also have the chance to disclose, with a sufficient level of granularity, which of her posts are sponsored.

Furthermore, the Omnibus Directive applies specifically to online marketplaces, defined as service providers "which allows consumers to conclude online contracts with traders and consumers on the online marketplace's online interface".156 It is evident that the majority of social media platforms will not be covered by such a definition.

Therefore, the Omnibus Directive does not offer a suitable framework for solving the core transparency need of influencer marketing.157 It is indeed still possible to argue for the existence of a design duty on the basis of the guidance on implementation/application of the UCPD. Such an interpretation would ensure a certain consistency with the duty already established in the AVMSD for video-sharing platforms. However, the circumstance that all the information duties envisaged in the Commission guidance on the UCPD have been codified in the Omnibus Directive, apart from the

Committee. A New Deal for Consumers). The European Parliament adopted its position at first reading on the $17^{\text {th }}$ of April 2019 (P8_TA-PROV(2019)0399). When "Omnibus Directive" is mentioned in this paper, the reference must be understood to the text proposed by the Commission.

${ }^{152}$ The proposal introduces a new provision in the Directive for Consumer Rights, establishing a duty for a platform to provide clear and comprehensible information about: 1) the criteria determining the ranking of the offers shown to consumers, 2) the identity of third-party providers (traders or not), 3) the application of consumer law, and 4) the allocation of liability among the platform and third-party suppliers. See Article 2(4) Omnibus Directive. Such transparency requirements were already envisaged for the UCPD instrument (see, Commission Staff Working document "Guidance on the implementation/application of Directive 2005/29/EC on Unfair Commercial Practices" accompanyning the document "Communication from the Commission to the European Parliament, the Council, the European Economic and Social Committee and the Committee of the Regions, A comprehensive approach to stimulating cross-border e-Commerce for Europe's citizens and businesses").

${ }^{153}$ Article 2(4) Omnibus Directive.

${ }^{154}$ See, in this sense, Busch, 'Self-Regulation and Regulatory Intermediation in the Platform Economy', 8-9.

${ }^{155}$ While, on the contrary, such a new transparency obligation will remedy an important problem in the collaborative economy, where consumers are usually misled about the identity (or legal nature) of the counterparty.

${ }^{156}$ Article 2(1) Omnibus Directive.

${ }^{157}$ Cf. Riefa and Clausen, 'Towards Fairness in Digital Influencers' Marketing Practices'. 
obligation to structure an interface in a way that allows the alignment of traders with relevant marketing and media laws, leaves the interpreter with the doubt that the European legislator tam dix quam voluit.

\section{Concluding remarks. Influencer marketing between regulation, self-regulation and co- regulation}

We may love them, hate them, make fun of them, but we ultimately follow them. For better or worse, influencers have become prominent figures in the Internet panorama. Their marketing power has been promptly understood by brands and companies, who are externalising larger slices of their marketing campaigns to SMIs. Introducing a product in the narrative of the daily life of the influencer or having it positively reviewed by an Internet celebrity has proven to be an effective modality for reaching and persuading a plethora of consumers.

This kind of activity is not prohibited by the law but it has to be conducted in line with the transparency requirements established by consumer, media and marketing laws. This contribution has offered a reconstruction of such obligations, distinguishing between the duties imposed on SMIs and platforms. The principle of transparency in commercial communications is in fact implemented differently depending on the actor involved: in the case of the influencer, it imposes some specific information duties about the legal classification of the person publishing the message (trader or not) and the sponsored nature of that act. While social media is an intermediary that allows the sharing of commercial communication, the principle of transparency is subsumed more precisely as a "design duty"158, i.e. an obligation to structure the interface in a way that favours transparent communication of an SMI's mandated disclosures.

The existing legal framework offers some possible instruments for tackling the issue of informing consumers about the commercial intent of a communication. However, the analysis has shown some potential inconsistencies and gaps in protection.

For instance, the UPCD's prohibition of misleading omissions is the main provision that can come into play in the context of influencer marketing but, as the national examples demonstrate, there is still considerable uncertainty as to when and how a disclosure of the commercial intent must be provided.

With reference to the first issue, i.e. when an influencer has the duty to disclose the commercial nature of her communication, the main challenge comes from the

\footnotetext{
${ }^{158}$ Christoph Busch, 'Self-Regulation and Regulatory Intermediation in the Platform Economy' (2019) Forthcoming in: Marta Cantero Gamito \& Hans-Wolfgang Micklitz (eds) The Role of the EU in Transnational Legal Ordering: Standards, Contracts and Codes, Edward Elgar .
} 
interpretations of the notions of "misleading practice", "material distortion of consumer behaviour" and, ultimately, of "average consumer". As we have seen, the Italian interpretation increases the standard of protection for the online user, while the German case law is profoundly divided.

To address such legal uncertainties and ensure a uniform protection for European consumers a possible solution de iure condendo could be to introduce an amendment to the blacklist of unfair commercial practices. Point 11, prohibiting the practice of advertorials without clear disclosure, could be modified so as to include UGC in the concept of editorial content. 159

Meanwhile, de iure condito, if we qualify blogs, online video channels and influencers' profiles as information society services, the cornerstone at the European level remains Article 6 of the E-Commerce Directive and its obligations to identify a commercial communication and the person on whose behalf that communication is made.

With reference to the design duties of platforms, coordination between the AVMSD and the UCPD should be supported. The AVSMD introduces some interesting mechanisms of co-regulation to increase the transparency of the online environment, encouraging platforms to create functionalities for users who upload user-generated videos to declare whether such videos contain audiovisual commercial communications. It would be unreasonable to confine such kind of solutions only to influencers' videos. As already stressed, similar design duties were already envisaged in the Guidance to the UCPD but not introduced in the Omnibus Directive. In order to ensure consistency in applying the principle of transparency in influencer marketing it would be appropriate to convey the Commission's suggestions into the black letter of the law. In parallel, education measures should be ensured in order to support the general awareness of influencers: not all users (influencers) will have the necessary knowledge to understand when they are acting as a trader or when their communication is an advertisement.160

As to the form of disclosure, in the absence of clear or mandatory indications from the legislator different standards and soft law have emerged at national and international levels. Soft law can indeed provide several useful recommendations to complement and explain with concrete examples the normative provisions. The Italian Code of SelfRegulation has been a valuable source in the field of advertising for more than fifty years. Recently, the IAP has also concluded a framework agreement to strengthen collaboration with the Italian Communication Authority in light of the new technological challenges emerging in the identification and assessment of commercial communication.161 These kinds of initiatives are certainly welcome. Self-regulation can constitute an efficient way to

\footnotetext{
${ }^{159}$ Agreeing with the proposal presented in Consortium, Behavioural Study on Advertising and Marketing Practices in Online Social Media, 47.

${ }^{160}$ Busch, 'Self-Regulation and Regulatory Intermediation in the Platform Economy', 9.

${ }^{161}$ https://www.iap.it/wp-content/uploads/2018/06/Accordo-quadro_AGCOM_IAP_amc.pdf
} 
respond to the challenges posed by the adoption of transparent modalities of disclosure, especially if such initiatives are done in liaison with supervisory authorities.

Another promising option would be to integrate the discourse on design duties within the development of European standards for platform services. 162 Such standards could represent a viable way for ensuring the participation of all the actors involved (enterprises, consumers, public authorities, NGOs, etc.) and make the rules across Europe more homogeneous.

However, the crucial point to guarantee in all the future recommendations and guidelines on the matter is to adopt a more "user-centred" approach. Existing standard of disclosures adopted at nation level (e.g. the use of the hashtag "\#adv" even at the beginning of a post) might not be sufficient to ensure the protection a consumer need. If we want to take the principle of transparency seriously we must investigate how the different ways to disclose the commercial intent influence the users' attention and which one is more appropriate for a given communication/platform. Empirical research could provide valuable insights to understand when a disclosure is effective for social media users, thus contributing to set up reliable standards and behavioural-based recommendations. 163

\footnotetext{
${ }^{162}$ European standards have been proposed as a possible regulatory alternative for platforms by Busch, 'Self-Regulation and Regulatory Intermediation in the Platform Economy', 16.

${ }^{163}$ It goes in this direction the interesting study by Arunesh Mathur, Arvind Narayanan, Marshini Chetty, Endorsements on social media: An empirical study of affiliate marketing disclosures on YouTube and Pinterest (2018). Proceedings of the ACM on Human-Computer Interaction, 2(CSCW) 119. The authors verified the level of compliance of affiliated marketing with the FTC's Endorsement guidelines and whether the different type of disclosure implemented helps users identify the post as advertisements.
} 